\title{
Uncoupling the Folding-Function Paradigm of Lytic Peptides to Deliver Impermeable Inhibitors of Intracellular Protein-Protein Interactions.
}

Stephen E. Miller ${ }^{1}$, Kohei Tsuji ${ }^{1}$, Rachel P.M. Abrams ${ }^{2}$, Terrence R. Burke Jr. ${ }^{1}$, and Joel P. Schneider ${ }^{1}$

${ }^{1}$ Chemical Biology Laboratory, National Cancer Institute, National Institutes of Health, Frederick, Maryland 21702, United States.

${ }^{2}$ Section of Infections of the Nervous System, National Institute of Neurological Disorders and Stroke, National Institutes of Health, Bethesda MD 20892, United States.

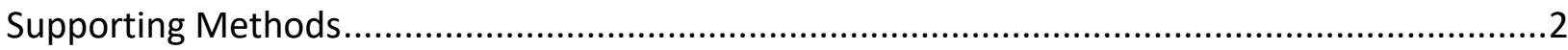

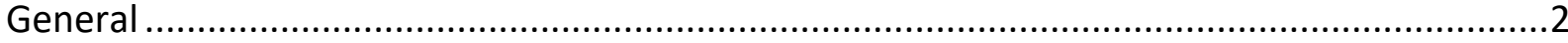

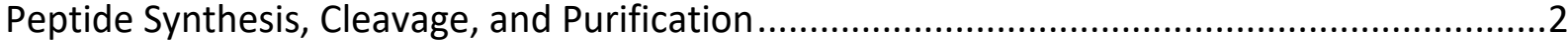

Synthesis of Halo-COOH and Halo-TAMRA ....................................................................

Circular dichroism (CD) spectroscopy to assess peptide folding .......................................

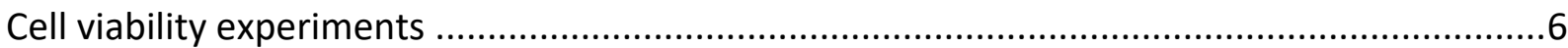

Hemolytic studies using human red blood cells .............................................................

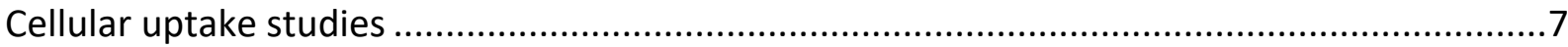

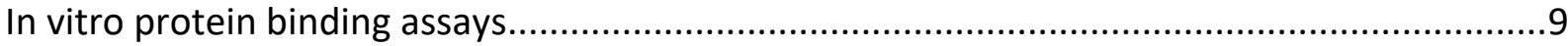

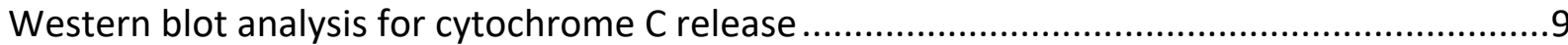

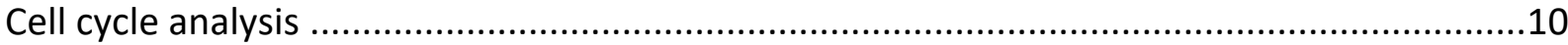

Figure S1. Structures of the lytic peptides and their respective N-methylated analogs. ............12

Figure S2. General synthesis for $\mathrm{N}$-methylated peptides. .....................................................13

Figure S3. HPLC and mass spec data for lytic peptides and N-methylated analogs. ..................14

Figure S4. CD spectra for peptides in buffer alone and with neutral POPC liposomes. ...............15

Figure S5. Cytotoxicity of peptides towards A549 and hemolytic potential. ...........................16

Figure S6. Uptake of fluorescein-labeled peptides..........................................................17

Figure S7. HPLC and mass spec data for additional peptides..........................................18

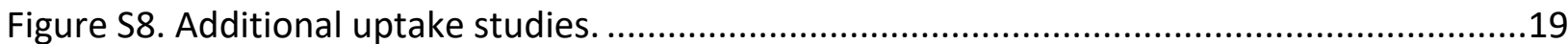

Figure S9. HPLC and mass spec data for BH3 peptides....................................................19

Figure S10. Cytotoxicity of BH3 peptides towards A549 cells. ..............................................20

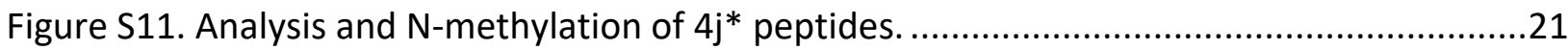

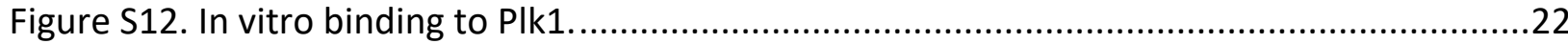

Figure S13. Cytotoxicity of $4 \mathrm{j}^{*}$ peptides towards A549 and HeLa cells. ................................22

Figure S14. Representative cell cycle dot plots for side-by-side treatment of U937 cells. .........23

Figure S15. U937 western blot analysis for cytochrome $\mathrm{C}$ release, NM $\Delta 1-4 \mathrm{j}^{*}$ vs $\mathrm{NM} \Delta 1-\mathrm{BH} 3 . \ldots .23$

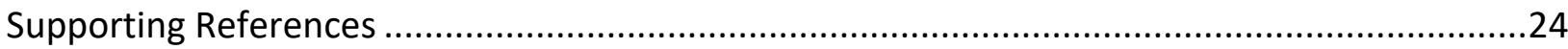




\section{Supporting Methods}

\section{General}

All chemicals, reagents, buffers, cell culture media, and kits were obtained from commercial vendors. POPC and POPS lipids were purchased from Avanti Polar Lipids. A549, HeLa, and U937 cells were purchased from ATCC. HPLC buffers consisted of Std A (0.1\% TFA in Milli-Q water) and Std B (80\% MeCN, $0.1 \%$ TFA, $19.9 \%$ Milli-Q water).

\section{Peptide Synthesis, Cleavage, and Purification}

Synthesis of unmodified lytic peptides: Peptides were synthesized on ProTide resin at a $0.1 \mathrm{mmol}$ scale $(0.56 \mathrm{mmol} / \mathrm{g})$ using a CEM Liberty Blue microwave-assisted peptide synthesizer. All Fmoc deprotection steps were performed using $20 \%$ piperidine in DMF at $90{ }^{\circ} \mathrm{C}$ for $1 \mathrm{~min}$. For the unmodified SVS1 and CLIPS peptides, the following coupling protocol was performed. The first 10 residues, up to D-Pro, were coupled using the standard microwave conditions of 5 eq of amino acid/DIC/Oxyma in DMF at $90^{\circ} \mathrm{C}$ for $4 \mathrm{~min}$ (single coupling for all residues, except double coupling for Arg). For the Val residue immediately following D-Pro, room temperature triple coupling was performed using 5/4.5/10 eq of amino acid/HCTU/DIEA in DMF (30 min for each coupling). The subsequent Lys (or Arg, in the case of CLIP $\triangle$ ) and Val residues were double coupled using room temperature HCTU/DIEA conditions. The last 5 residues were added using the standard DIC/Oxyma conditions. For the unmodified M-lycotoxin, all coupling steps were performed with standard DIC/Oxyma conditions. At the end of each synthesis, the terminal Fmoc was deprotected. The resin was removed from the synthesizer and then dried on a vacuum manifold.

Synthesis of $\mathbf{N}$-methylated analogs: Peptides were synthesized as described above for their respective parent sequences, up through the coupling and Fmoc deprotection of the first intended N-methylated residue (step 1, Figure S2). The intermediate peptide-containing resin was removed from the synthesizer and transferred to an empty SPE tube for manual synthesis of the Fukuyama-Mitsunobu alkylation and secondary amine coupling steps. The resin was then swelled in $3 \mathrm{~mL}$ NMP for $10 \mathrm{~min}$. Collidine (132 $\mu \mathrm{L}, 5 \mathrm{eq}$ ) and Nosyl-chloride (110 mg, 5 eq) were added to the SPE tube, then the reaction was shaken on a wrist action shaker for 30 min (step 2, Figure S2). The resin was washed with NMP and DCM, then dried under a vacuum manifold for 1 $\mathrm{hr}$. The resin was then swelled in $3 \mathrm{~mL}$ of dry THF for $15 \mathrm{~min}$, followed by the addition of $\mathrm{PPh}_{3}$ (260 mg, $10 \mathrm{eq}$ ) and HPLC-grade $\mathrm{MeOH}(83 \mu \mathrm{L}, 20 \mathrm{eq}$ ). The SPE tube was briefly shaken by hand to dissolve the $\mathrm{PPh}_{3}$. DIAD was added in $4 \times 50 \mu \mathrm{L}$ aliquots ( $200 \mu \mathrm{L}$ total, $10 \mathrm{eq}$ ), with a few minutes of shaking between each addition and $30 \mathrm{~min}$ after the last aliquot (step 3, Figure S2). The resin was washed (NMP, DCM) and then swelled in $3 \mathrm{~mL}$ NMP. $\beta$-mercaptoethanol ( $\beta M E, 70 \mu \mathrm{L}, 10$ eq) and DBU (75 $\mathrm{LL}, 5 \mathrm{eq}$ ) were added to the resin and shaken for $5 \mathrm{~min}$ (step 4, Figure S2). The reaction was drained and repeated for $10 \mathrm{~min}$, then washed (NMP/DCM) and dried for $30 \mathrm{~min}$. The resin was swelled in $3 \mathrm{~mL}$ of dry NMP (15 min) and the secondary amine underwent a double coupling procedure using 10/10/20 eq of amino acid/PyAOP/DIEA ( $3 \mathrm{hr}$, then overnight; step 5, Figure S2). After washing, the resin was then put back onto the synthesizer and followed the synthesis protocol described for the parent peptides until the sequences were complete (NMS1, $\mathrm{NM} \triangle 1, \mathrm{NMM} 1$ ) or until after the next intended $\mathrm{N}$-methylated residue was coupled/Fmoc 
deprotected (NMS2, NM $\Delta 2, \mathrm{NMM} 2$ ). For the latter sequences, the protocol for $\mathrm{N}$-methylation was repeated and the final sequence was completed using the respective synthesis protocol.

Synthesis of CLIP6 and TAT peptides: CLIP6 was synthesized on $0.1 \mathrm{mmol}$ scale as described above for the unmodified SVS1 and CLIPS, utilizing a mixture of standard DIC/Oxyma and HCTU/DIEA conditions. TAT ${ }^{48-60}$ was synthesized using standard DIC/Oxyma conditions.

Fluorescent labeling of peptides: Aliquots of terminally Fmoc deprotected resin ( $0.025 \mathrm{mmol}$ ) containing either SVS1, NMS1/2, CLIP $\Delta, \mathrm{NM} \Delta 1 / 2$, M-lycotoxin, NMM1/2, CLIP6, or TAT ${ }^{48-60}$ peptides were reacted with NHS-fluorescein $(25 \mathrm{mg}, \sim 2$ eq, mixed 5/6 isomer) in $1 \mathrm{~mL} \mathrm{NMP} \mathrm{on} \mathrm{a}$ manual wrist-action shaker overnight. The resin was washed with NMP and DCM, then dried.

Synthesis of chloroalkane-tagged peptides: Aliquots of terminally Fmoc deprotected resin ( $\sim 0.025 \mathrm{mmol}$ ) containing either SVS1, CLIP6, NM $\triangle 1, \mathrm{NMM1}$, or $\mathrm{TAT}^{48-60}$ were reacted with a 1 $\mathrm{mL}$ DMF solution containing Halo-COOH (32 mg, 4 eq), PyAOP (65 mg, 5 eq), and DIEA (44 $\mu \mathrm{L}, 10$ eq). The reaction was placed on a manual wrist-action shaker overnight. The resin was washed with DMF and DCM, then dried.

Synthesis of BH3 peptides: The Bim-BH3 peptide was synthesized on the Liberty Blue with the standard DIC/Oxyma conditions. For the unconjugated $\mathrm{BH}$, the peptide underwent terminal Fmoc deprotection, followed by N-terminal capping with $10 \%$ acetic anhydride in DMF. For $\mathrm{NM} \Delta 1-\mathrm{BH} 3$, a GlyGlySerGlySer linker was installed after the $\mathrm{BH} 3$ domain, and the $\mathrm{NM} \Delta 1$ sequence was synthesized as described above with one exception. Room temperature triple/double/double couplings of $\mathrm{Val} / \mathrm{Arg} / \mathrm{Val}$ residues after the D-Pro were performed with HATU rather than HCTU.

Synthesis of $4 j^{*}$ peptides: Pentameric peptides $4 j^{*}$ and $4 j^{*} S 4 A$ were made by manual peptide synthesis, using $20 \%$ piperidine for Fmoc deprotection (10 min) and coupling with 4/3.8/8 eq of amino acid/HATU/DIEA ( $2 \mathrm{hr}$ to overnight). For unconjugated peptides, terminal Fmoc deprotection was performed, followed by $\mathrm{N}$-terminal acetyl capping. For $N M \Delta 1-4 \mathrm{j} * / 4 \mathrm{j} * \mathrm{~S} 4 \mathrm{~A}, \mathrm{a}$ GlyGlySerGlySer linker was installed after the Plk1 ligand domain, and the NM $\Delta 1$ sequence was synthesized as described above with some exceptions. An initial synthesis utilizing the FukuyamaMitsunobu $\mathrm{N}$-alkylation resulted in an inseparable side product where methylation also occurred at the modified His residue of $4 \mathrm{j}^{*}$. To circumvent this, we stopped the automated synthesis after the first Arg residue of the $\mathrm{NM} \Delta 1$ domain, rather than at the intended $\mathrm{N}$-methylated Val position. We then performed manual coupling with 5/5/10 eq of Fmoc-NMe-Val-OH/PyAOP/DIEA in 50\% DMSO/DMF overnight (see Figure S9B). The resin was washed the next day with DMF/DCM, deprotected $2 x$ with $20 \%$ piperidine, washed again, and subjected to double coupling with 10/10/20 eq of Arg/PyAOP/DIEA in dry NMP (3 hours, then overnight). The resin was washed and then placed back onto the synthesizer to complete the synthesis as above, with room temperature triple/double/double coupling of Val/Arg/Val residues after the D-Pro performed with HATU rather than HCTU. 
Peptide cleavage from resin and purification: Most of the peptides were cleaved from the resin using a cocktail of $95 \%$ TFA, $2.5 \%$ TIPS, and $2.5 \% \mathrm{H}_{2} \mathrm{O}$ for $3 \mathrm{hr}$, however, Bim-BH3 and NM $\triangle 1$ BH3 were cleaved using $90 \%$ TFA, $5 \%$ thioanisole, $3 \%$ ethanedithiol, and $2 \%$ anisole. The resin was then filtered and the collected filtrate was concentrated by a stream of argon. Following ether precipitation, crude solids were dried under vacuum. All peptides were purified by prepHPLC. Crude peptides were dissolved in Std A (0.1 \% TFA in Milli-Q water; 3-4 mg/mL for most peptides; $2 \mathrm{mg} / \mathrm{mL}$ for fluorescently labeled peptides and $\mathrm{NM} \Delta 1-\mathrm{BH} 3$ ), syringe filtered, and $5 \mathrm{~mL}$ per run was injected into a Waters 600 system, equipped with a Waters 2489 UV Detector and a Vydac $218 \mathrm{TP}$ column $\left(250 \times 22 \mathrm{~mm}, 10 \mu \mathrm{m}\right.$, heated to $\left.40^{\circ} \mathrm{C}\right)$. A gradient of $1 \% \mathrm{Std} B(80 \% \mathrm{MeCN}$, $0.1 \%$ TFA, and $19.9 \%$ Milli-Q water) per min was used for $20 \mathrm{~min}$, followed by $0.5 \%$ Std B per min for the remaining portion of the run. The UV trace at $220 \mathrm{~nm}$ was monitored and fractions containing the major peptide peak were combined and lyophilized. Purity was assessed by LCMS (Shimadzu LCMS 2020) and analytical HPLC (Agilent 1200 series, Vydac 218TP column, $250 \times 4.6$ $\mathrm{mm}, 5 \mu \mathrm{m}$, heated to $40^{\circ} \mathrm{C}$ ) using gradients of $1 \%$ Std $B$ per min.

\section{Synthesis of Halo-COOH and Halo-TAMRA}

The following procedures largely follow previously reported protocols. ${ }^{1}$

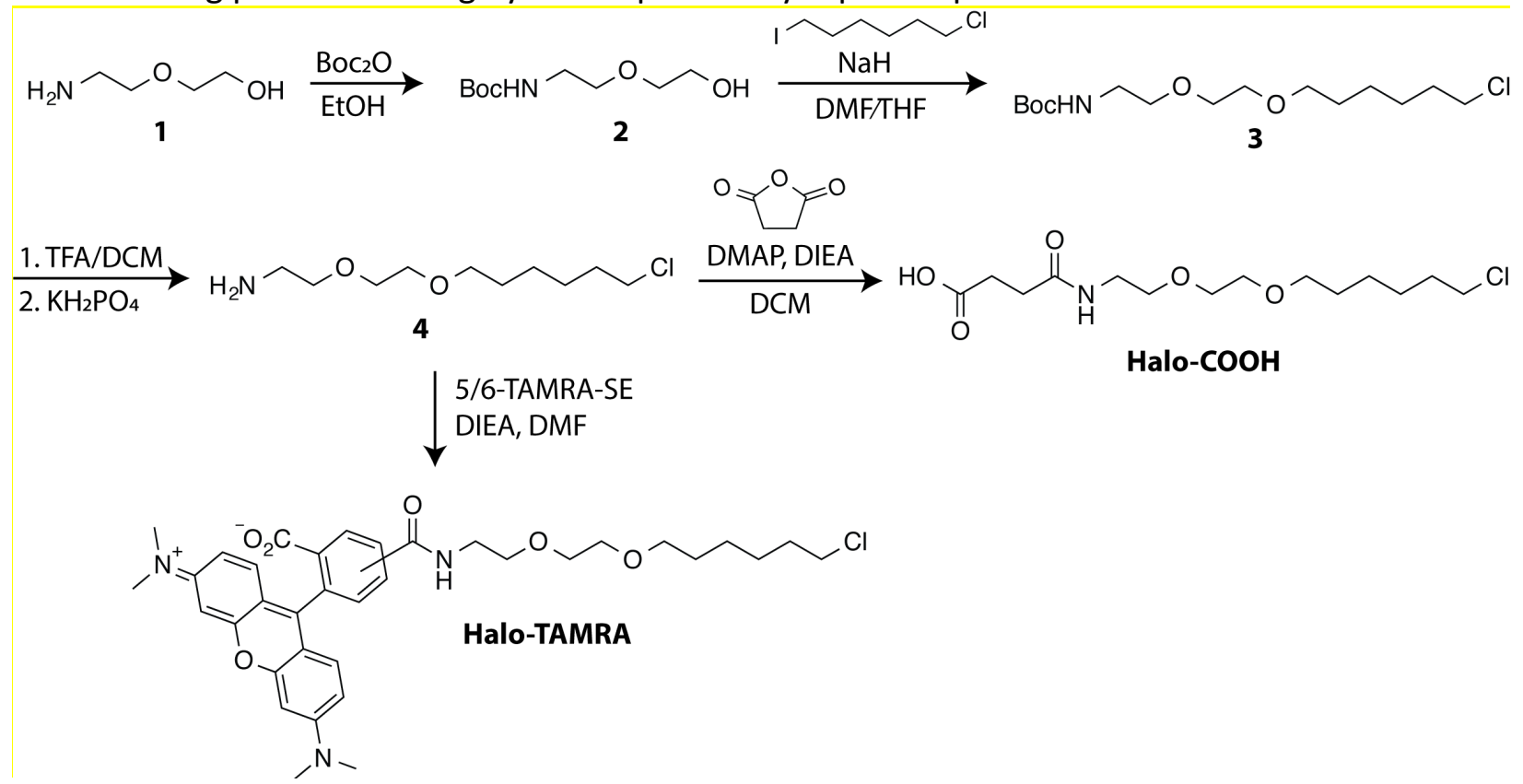

Synthesis of Tert-butyl(2-(2-hydroxyethoxy)ethyl)carbamate (2): 2-(2-aminoethoxy)ethan-1-ol $(1,1.25 \mathrm{~g}, 11.9 \mathrm{mmol})$ was dissolved in anhydrous $\mathrm{EtOH}(11 \mathrm{~mL})$, kept under $\mathrm{N}_{2}$, and cooled to 0 ${ }^{\circ} \mathrm{C}$ in an ice bath. Di-tert-butyl dicarbonate $(2.73 \mathrm{~mL}, 11.9 \mathrm{mmol})$ was slowly added via syringe over several minutes. The reaction was removed from the ice bath and stirred at room temperature for $2 \mathrm{hr}$. After the reaction was complete, the solvent was removed under vacuum. The crude product was redissolved in DCM $(5 \mathrm{~mL})$, then washed with water $(5 \mathrm{~mL})$ and brine $(5$ $\mathrm{mL}$ ). The organic layer was dried over $\mathrm{Na}_{2} \mathrm{SO}_{4}$, filtered, and concentrated under vacuum to yield $\mathbf{2}$ as a colorless oil, which was used without further purification. 
Synthesis of Tert-butyl(2-(2-((6-chlorohexyl)oxy)ethoxy)ethyl)carbamate (3): Sodium hydride ( $0.56 \mathrm{~g}$ of $60 \%$ mineral oil dispersion, $13.9 \mathrm{mmol}, 1.3 \mathrm{eq}$ ) was added to a flame dried flask, cooled on an ice-water bath, and purged with nitrogen. The solid was stirred with dry hexanes (10 $\mathrm{mL})$ and then allowed to settle, after which the solvent was removed by syringe and under high vacuum. Anhydrous THF $(7.9 \mathrm{~mL})$ was then added to the flask, followed by the dropwise addition of 2 (2.2 g, $10.7 \mathrm{mmol})$ dissolved in dry DMF $(7.9 \mathrm{~mL})$. The mixture was stirred for 30 min on ice, then 1-chloro-6-iodohexane $(2.44 \mathrm{~mL}, 16.1 \mathrm{mmol}, 1.5 \mathrm{eq})$ was added dropwise. The reaction was allowed to warm to room temperature and stirred overnight under nitrogen. After completion, saturated $\mathrm{NH}_{4} \mathrm{Cl}(20 \mathrm{~mL})$ was added and stirred for about $15 \mathrm{~min}$. The reaction was transferred to a separatory funnel, the organic layer was removed, and the aqueous phase was backextracted with EtOAc $(3 \times 10 \mathrm{~mL})$. The organic phases were combined, then washed with water $(20 \mathrm{~mL})$ and brine $(20 \mathrm{~mL})$. After drying with $\mathrm{Na}_{2} \mathrm{SO}_{4}$ and filtering, the solvent was removed under vacuum. The crude oil was then purified by silica gel chromatography, using a gradient of 2:1 hexane:EtOAc to 1:1 hexane:EtOAc, to yield 3 as a colorless oil $(0.64 \mathrm{~g}) .{ }^{1} \mathrm{H} \mathrm{NMR}\left(400 \mathrm{MHz}, \mathrm{CDCl}_{3}\right)$ $\delta 5.01$ (br s, $1 \mathrm{H}), 3.62-3.51(\mathrm{~m}, 8 \mathrm{H}), 3.47(\mathrm{t}, 2 \mathrm{H}), 3.34-3.30(\mathrm{~m}, 2 \mathrm{H}), 1.82-1.75(\mathrm{~m}, 2 \mathrm{H}), 1.65-1.57$ $(\mathrm{m}, 2 \mathrm{H}), 1.47-1.35(\mathrm{~m}, 13 \mathrm{H})$. Calculated $[\mathrm{M}+\mathrm{Na}]^{+}: 346.2 \mathrm{~m} / \mathrm{z}$; observed ESI-MS: $346.2 \mathrm{~m} / \mathrm{z}$.

Synthesis of 2-(2-((6-chlorohexyl)oxy)ethoxy)ethan-1-amine (4, Halo- $\left.\mathrm{NH}_{2}\right)$ : Compound 3 (0.64 g $\mathrm{mg}, 1.97 \mathrm{mmol})$ was dissolved in DCM $(4.6 \mathrm{~mL})$. TFA $(1.6 \mathrm{~mL})$ was then added and the reaction was stirred for $3.5 \mathrm{hr}$ at room temperature. The solvent was removed under vacuum, then redissolved in DCM $(10 \mathrm{~mL})$ and the solvent removed again to reduce excess TFA. This process was repeated a total of 3 times, after which DCM $(10 \mathrm{~mL})$ was added and stirred with $1 \mathrm{M} \mathrm{KH}_{2} \mathrm{PO}_{4}$ $(20 \mathrm{~mL})$ for 15 minutes. After transfer to a separatory funnel, the DCM phase was removed, and the aqueous phase was extracted with $2 \times 15 \mathrm{~mL}$ DCM. The organic layers were combined, then washed with $15 \mathrm{~mL}$ water and $15 \mathrm{~mL}$ brine. The organic layer was dried over $\mathrm{Na}_{2} \mathrm{SO}_{4}$, filtered, and concentrated under vacuum. Crude 4 was obtained as a yellow oil without further purification $(0.40 \mathrm{~g}, 1.79 \mathrm{mmol})$. Calculated $[\mathrm{M}+\mathrm{H}]^{+}: 224.1 \mathrm{~m} / \mathrm{z}$; observed ESI-MS: $224.1 \mathrm{~m} / \mathrm{z}$.

Synthesis of Halo-COOH: Crude 4 (0.38 g, $1.7 \mathrm{mmol})$ was dissolved in $3 \mathrm{~mL} \mathrm{DCM}$ and stirred under argon. DIEA ( $0.88 \mathrm{~mL}, 5.1 \mathrm{mmol}, 3 \mathrm{eq})$ and 4-dimethylaminopyridine $(0.10 \mathrm{~g}, 0.5 \mathrm{eq})$ were added to the solution, followed by a portion-wise addition of succinic anhydride (total amount $0.34 \mathrm{~g}$, $3.4 \mathrm{mmol}, 2 \mathrm{eq}$ ). The flask was purged with argon and left stirring overnight at room temperature ( $15 \mathrm{hr}$ ). $15 \mathrm{~mL}$ of $1 \mathrm{M} \mathrm{HCl}$ was added to the flask and stirred for $30 \mathrm{~min}$ to quench the reaction. After transfer to a separatory funnel, the DCM phase was removed, and the aqueous phase was extracted with $2 \times 15 \mathrm{~mL}$ DCM. The organic layers were combined, then washed with $15 \mathrm{~mL}$ water and $15 \mathrm{~mL}$ brine. The organic layer was dried over $\mathrm{Na}_{2} \mathrm{SO}_{4}$, filtered, and concentrated under vacuum. The crude product was a dark brown oil, which was solubilized at $5 \mathrm{mg} / \mathrm{mL}$ in $10 \%$ Std B, and purified by prep-HPLC (0\% B over $2 \mathrm{~min}, 0-100 \%$ B in $100 \mathrm{~min}$, elutes around $49 \mathrm{~min}$ ). The purified product was lyophilized to yield $\mathrm{Halo}-\mathrm{COOH}$ as a white solid. ${ }^{1} \mathrm{H} \mathrm{NMR}\left(400 \mathrm{MHz}, \mathrm{CDCl}_{3}\right)$ $\delta 6.40(\mathrm{~s}, 1 \mathrm{H}), 3.65-3.47(\mathrm{~m}, 12 \mathrm{H}), 2.70(\mathrm{t}, 2 \mathrm{H}), 2.55(\mathrm{t}, 2 \mathrm{H}), 1.84-1.77(\mathrm{~m}, 2 \mathrm{H}), 1.69-1.62(\mathrm{~m}, 2 \mathrm{H})$, 1.52-1.36 (m, 4H). Calculated $[\mathrm{M}+\mathrm{H}]^{+}: 324.2 \mathrm{~m} / \mathrm{z}$; observed ESI-MS: $324.2 \mathrm{~m} / \mathrm{z}$.

Synthesis of Halo-TAMRA: Crude 4 ( $5 \mathrm{mg}, 22 \mu \mathrm{mol}$ ) was dissolved in $200 \mu \mathrm{L}$ of DMF. DIEA (32 $\mu \mathrm{L}$, $184 \mu \mathrm{mol}$ ) was added to the vial, followed by 5/6-TAMRA-succinimidyl ester (10 mg, $19 \mu \mathrm{mol})$. 
The vial was purged with argon and stirred at room temperature for $5 \mathrm{hr}$ in the dark. The reaction mixture was then diluted to $10 \mathrm{~mL}$ with Std $A$, then purified by prep-HPLC over two runs with 5 $\mathrm{mL}$ injections each (0\% B over $2 \mathrm{~min}, 0-100 \% \mathrm{~B}$ in $100 \mathrm{~min}$, elutes around $60 \mathrm{~min}$ ). Purified product was lyophilized to yield Halo-TAMRA as a purple solid. Calculated $[\mathrm{M}+\mathrm{H}]^{+}: 636.3 \mathrm{~m} / \mathrm{z}$; observed ESI-MS: $636.3 \mathrm{~m} / \mathrm{z}$.

\section{Circular dichroism (CD) spectroscopy to assess peptide folding}

CD spectra were collected on either an Aviv Model 420 Spectrometer or a Jasco J-1500 Spectrometer, using $50 \mu \mathrm{M}$ peptide in either buffer alone (50 mM BTP, $150 \mathrm{mM} \mathrm{KF,} \mathrm{pH} \mathrm{7.4),}$ buffer containing neutral POPC liposomes, or buffer containing negatively charged POPC:POPS liposomes (lipid:peptide ratio of 50:1; all peptides used 1:1 ratio of POPC:POPS, except for Mlycotoxin and its analogs, which used 4:1 POPC:POPS). Liposomes were prepared and extruded to $100 \mathrm{~nm}$ as previously described. ${ }^{2}$ The sample, in a $1 \mathrm{~mm}$ pathlength cuvette, was placed into the instrument's pre-heated sample holder $\left(37^{\circ} \mathrm{C}\right)$ and equilibrated for $5 \mathrm{~min}$. Wavelength scans were then carried out at $37^{\circ} \mathrm{C}$ between 260 and $200 \mathrm{~nm}$ at $1 \mathrm{~nm}$ intervals, with an averaging time of $3 \mathrm{sec}$ at each wavelength. A background spectrum of blank buffer was subtracted from the sample spectra and the mean residue ellipticity $[\theta]$ was calculated from the equation $[\theta]=$ $\left(\theta_{\text {obs }} / 10 / c\right) / r$, where $\theta_{\text {obs }}$ is the measured ellipticity in millidegrees, $l$ is the length of the cell in centimeters $(0.1 \mathrm{~cm}), c$ is the molar concentration $(0.00005 \mathrm{M})$, and $r$ is the number of peptide bonds (18 for hairpin-based peptides, 25 for M-lycotoxin and its derivatives).

\section{Cell viability experiments}

HeLa (DMEM), A549 (RPMI), and U937 (RPMI) cells were maintained in T75 flasks using complete media (10\% FBS and $2 \mathrm{mM}$ GlutaMAX), and incubated at $37{ }^{\circ} \mathrm{C}$ with $5 \% \mathrm{CO}_{2}$ and humidity control.

HeLa and A549 viability: Cells were trypsinized with $3 \mathrm{~mL} 0.25 \%$ trypsin-EDTA solution for $5 \mathrm{~min}$, diluted with $7 \mathrm{~mL}$ media, pelleted by centrifugation, and reconstituted in media. The viable cells were counted using trypan blue staining and the cells were diluted to $5 \times 10^{4}$ viable cells $/ \mathrm{mL}$. 100 $\mu \mathrm{L}$ of diluted cells was pipetted into wells of a clear 96 well tissue culture treated plate $(5,000$ cells per well), then grown overnight ( $\sim 16 \mathrm{hr}$ ). Serial dilutions of each peptide were made in serum-free RPMI. The overnight culture media was removed from the cells and replaced with the peptide-containing media and incubated for $24 \mathrm{hr}$. Cells were also incubated in media without peptide and media with $20 \%$ DMSO, as negative and positive controls, respectively. After a day, the media was removed and the cells were washed with $100 \mu \mathrm{L}$ media. After removal of the wash, $100 \mu \mathrm{L}$ media was added to cells, plus $10 \mu \mathrm{L}$ of MTT solution ( $5 \mathrm{mg} / \mathrm{mL}$ in Milli-Q water). The samples were incubated for 3 hours, after which the media was removed and $150 \mu \mathrm{L}$ of spectroscopic grade DMSO was added. The plates were incubated at $37^{\circ} \mathrm{C}$ with light rocking for $15 \mathrm{~min}$, then read at $540 \mathrm{~nm}$ using a UV plate reader (Biotek Epoch). The absorbance of the positive controls was subtracted from each sample, and percent viability was calculated using the equation: (Abstreated/Abs untreated $_{\text {) }}$ x 100. IC $_{50}$ values were computed using Graphpad Prism 8 software and represented the average of three independent experiments, each in triplicate $(\mathrm{N}=$

9). In main text Figure $3 \mathrm{~A}$, the normalized toxicity was determined by taking the inverse of the 
IC50 values for each peptide and normalizing it to SVS1. The data was presented on a log scale and compared to the normalized uptake.

U937 viability: Cells were pelleted, resuspended in serum-free media, counted, and diluted to 2 $\times 10^{5}$ viable cells $/ \mathrm{mL}$. Serial dilutions of $2 \times$ stocks for each peptide were made in serum-free RPMI. $50 \mu \mathrm{L}$ of diluted cells were added to the wells of a white 96 well non-treated plate $(10,000$ cells per well), followed by $50 \mu \mathrm{L}$ of the $2 x$ peptide stocks (or blank media for control) and incubation for $24 \mathrm{hr}$. The next day, $100 \mu \mathrm{L}$ of Cell Titer Glo reagent (Promega) was added to each well. The plates were incubated at $37^{\circ} \mathrm{C}$ with light rocking for $2 \mathrm{~min}$, rocked for an addition $15 \mathrm{~min}$ at room temperature, then the luminescence was read using a Biotek Synergy Neo2 plate reader. Percent viability was calculated using the equation: (Lum treated $_{\text {Lum }}$ untreated) $\times 100 . I_{50}$ values were computed using Graphpad Prism 8 software and represented the average of three independent experiments, each in triplicate $(\mathrm{N}=9)$.

\section{Hemolytic studies using human red blood cells}

Human blood was obtained from the NCl-Frederick Research Donor Program. $2 \times 3 \mathrm{~mL}$ of blood was collected in BD Vacutainer K2EDTA tubes, then spun down for $10 \mathrm{~min}$ at $3000 \mathrm{rpm}, 4^{\circ} \mathrm{C}$. The supernatant was removed and the pelleted red blood cells (RBCs) were resuspended in $1 x$ hemolysis buffer (10 mM Tris, $150 \mathrm{mM} \mathrm{NaCl}, \mathrm{pH}$ 7.4), transferred to $2 \times 15 \mathrm{~mL}$ centrifuge tubes, then centrifuged. The cells were washed twice more with buffer. After removal of the final wash supernatant, $50 \mu \mathrm{L}$ of pelleted cells was transferred to $20 \mathrm{~mL}$ of buffer $(0.25 \% \mathrm{RBC}) .4 \mathrm{mM}$ peptide stocks were made in Milli- $Q$ water, then diluted by the addition of an equal volume of $2 x$ buffer to make $2 \mathrm{mM}$ peptide in $1 \mathrm{x}$ buffer. 10-fold serial dilutions of each peptide were made. 75 $\mu \mathrm{L}$ of $0.25 \%$ RBC were added to a clear 96 well plate, plus $75 \mu \mathrm{L}$ of the peptide dilutions. For controls, $75 \mu \mathrm{L}$ of either blank buffer or $1 \%$ Triton X-100 were added instead of peptide. The plates were then placed into an orbital shaker set to $37^{\circ} \mathrm{C}$ for $24 \mathrm{hr}$. After a day, the plates were centrifuged for $10 \mathrm{~min}$ at $3000 \mathrm{rpm}, 4^{\circ} \mathrm{C}$, then $100 \mu \mathrm{L}$ from each well was transferred to a new plate and was read at $415 \mathrm{~nm}$ in a Biotek Epoch plate reader. The absorbance of the untreated control was subtracted from each sample, and percent hemolysis was calculated using the equation: (Abstreated $/ A b S_{\text {Tritonx }}$ ) x 100. $\mathrm{EC}_{50}$ values were computed using Graphpad Prism 8 software. This procedure was performed using blood from two separate donors, with each performed in triplicate $(\mathrm{N}=6)$.

\section{Cellular uptake studies}

Flow cytometry: A549 (RMPI) or HeLa (DMEM) cells were diluted to $5 \times 10^{5}$ viable cells $/ \mathrm{mL}$ in complete media, then $0.5 \mathrm{~mL}$ was added to clear 24 well tissue culture treated plates $\left(2.5 \times 10^{5}\right.$ cells per well) and incubated overnight ( $16 \mathrm{hr}$ ) at $37{ }^{\circ} \mathrm{C}$ with $5 \% \mathrm{CO}_{2}$. The next day, stocks of fluorescently-labeled peptide were made in buffer and the concentrations were determined by UV absorbance (fluorescein: $\varepsilon_{494}=70,000 \mathrm{M}^{-1}$ ) and diluted to $2 \mu \mathrm{M}$ in serum-free media. After removal of the overnight culture media, $0.5 \mathrm{~mL}$ peptide solution was added to the wells and incubated for $1 \mathrm{hr}$. The cells were then washed with media and incubated with $150 \mu \mathrm{L}$ of $0.25 \%$ trypsin-EDTA solution for $15 \mathrm{~min}$. The cells were diluted with $0.5 \mathrm{~mL}$ cold PBS, transferred to 12 x $75 \mathrm{~mm}$ polystyrene tubes, placed on ice, and then analyzed by flow cytometry using a BD 
FACSCalibur instrument. Additional experiments were also conducted to assess the mechanisms of peptide uptake. ATP depletion and $4{ }^{\circ} \mathrm{C}$ experiments inhibit all energy dependent processes, while treatment with hyperosmolar sucrose, EIPA, and nystatin inhibit clathrin-mediated uptake, macropinocytosis, and caveolae-mediated uptake, respectively. Prior to peptide incubation, cells were pretreated with media for either ATP depletion (glucose-free and serum-free RPMI/DMEM, $10 \mathrm{mM}$ sodium azide, and $50 \mathrm{mM}$ 2-deoxy-D-glucose, $30 \mathrm{~min}$ ), hyperosmolar sucrose (serum-free RPMI/DMEM, $0.45 \mathrm{M}$ sucrose, $1 \mathrm{hr}$ ), $50 \mu \mathrm{M}$ EIPA (serum-free RPMI/DMEM, $1 \mathrm{hr}$ ), or $50 \mu \mathrm{M}$ nystatin (serum-free RMPI/DMEM, $1 \mathrm{hr}$ ), followed by peptide incubation in respective media at $37^{\circ} \mathrm{C}$. For the $4{ }^{\circ} \mathrm{C}$ experiments, cells were pretreated with chilled serum-free media for $1 \mathrm{hr}$ at 4 ${ }^{\circ} \mathrm{C}$, then incubated with peptide at $4{ }^{\circ} \mathrm{C}$. All flow cytometry experiments are represented as the average of three independent experiments, each in triplicate $(\mathrm{N}=9)$, except for the $4{ }^{\circ} \mathrm{C}$, EIPA, and nystatin experiments which were done in two independent experiments, each in triplicate $(\mathrm{N}=6)$. In main text Figure $3 \mathrm{~A}$, the mean fluorescent uptake values were normalized to SVS1 and presented on a log scale next to normalized cytotoxicity values.

Live cell imaging by confocal microscopy: A549 (RPMI) or HeLa (DMEM) cells were to diluted to $5 \times 10^{4}$ viable cells $/ \mathrm{mL}$ in media and $2 \mathrm{~mL}$ was added to circular glass slides ( $1 \times 10^{5}$ cells per slide). The cells were incubated overnight at $37{ }^{\circ} \mathrm{C}$ with $5 \% \mathrm{CO}_{2}$. The next day, a stock of fluorescently labelled $N M \Delta 1$ was made in buffer and the concentration was determined by UV absorbance (fluorescein: $\varepsilon_{494}=70,000 \mathrm{M}^{-1}$ ) and diluted to $5 \mu \mathrm{M}$ in serum-free media. After removal of the overnight culture media, $2 \mathrm{~mL}$ of the peptide solution was added to the slides and incubated for $5 \mathrm{hr}$. After $4.5 \mathrm{hr}$ of incubation, $2 \mu \mathrm{L}$ of $1 \mathrm{mg} / \mathrm{mL}$ Hoescht 33342 dye was added to the slides, the solution was gently mixed, and the samples were incubated for an additional $30 \mathrm{~min}$. The cells were then washed with media and imaged using a Zeiss LSM710 Confocal Microscope with an environmental chamber to maintain $37^{\circ} \mathrm{C}$ and $5 \% \mathrm{CO}_{2}$. Microscopy images were processed using ImageJ. A similar procedure was also done for NMM1 in HeLa cells.

Chloroalkane penetration assay ${ }^{1,3}$ : HeLa cells with stable transfection of Halo-GFP-Mito were cultured in DMEM containing 10\% FBS, $1 \%$ pen/strep, $1 \%$ GlutaMAX, and $1 \mu \mathrm{g} / \mathrm{mL}$ puromycin. ${ }^{4}$ Cells were diluted to $4 \times 10^{5}$ cells $/ \mathrm{mL}$ and $100 \mu \mathrm{L}$ was added to wells of a 96-well plate $\left(4 \times 10^{4}\right.$ cells per well). The cells were incubated overnight at $37^{\circ} \mathrm{C}$ with $5 \% \mathrm{CO}_{2}$. The next morning, media was removed from the cells and replaced with $100 \mu \mathrm{L}$ serum-free DMEM. Fresh $500 \mu \mathrm{M}$ chloroalkane-tagged peptide stocks in water were prepared for each experiment. Serial dilutions for each ct-peptide were made in a different 96 well plate using serum-free $\operatorname{DMEM}(100,50,25$, $10,5,2.5,1,0.5 \mu \mathrm{M})$, then $25 \mu \mathrm{L}$ of the peptides were added to the cells and incubated for $4 \mathrm{hr}$ (final peptide concentrations in $125 \mu \mathrm{L}$ after dilution: 20, 10, 5, 2, 1, 0.5, 0.2, $0.1 \mu \mathrm{M}$ ). The media was removed, $80 \mu \mathrm{L}$ DMEM was added, and the cells were incubated for $15 \mathrm{~min}$ at room temperature. After removal of the media, the cells were treated with $50 \mu \mathrm{L}$ of $5 \mu \mathrm{M}$ Halo-TAMRA and incubated for $15 \mathrm{~min}$ at room temperature. The media was removed and replaced with 80 $\mu \mathrm{L}$ DMEM and incubated for $30 \mathrm{~min}$ at room temperature. The media was removed, the cells were treated with $40 \mu \mathrm{L}$ trypsin-EDTA for 5 min at $37^{\circ} \mathrm{C} .200 \mu \mathrm{L}$ of cool PBS was added to each well, transferred to polystyrene flow tubes, placed on ice, and then analyzed by flow cytometry using a BD FACSCanto II instrument. Results represent the average of two independent experiments, each in duplicate $(\mathrm{N}=4)$. 


\section{In vitro protein binding assays}

4j* peptides: Assays were conducted as previously reported. ${ }^{5}$ To summarize, a plasmid encoding myc-tagged full-length Plk1 (Addgene, Plasmid \#41160) was transiently transfected into HEK293T cells using TurboFect reagent (Thermo Scientific) according to manufacturer's instructions. Following $48 \mathrm{hr}$ expression, cells were harvested, lysed in buffer (PBS, pH 7.4 with 0.5\% NP-40 and a cocktail of protease/phosphatase inhibitors [Pierce]) using freeze/thaw cycles (3x) and centrifuged at $10,000 \mathrm{~g}$ for $10 \mathrm{~min}$ at $4{ }^{\circ} \mathrm{C}$. The supernatant was removed to provide a crude cytosolic lysate containing overexpressed, myc-tagged Plk1. Total protein concentration was determined by the BCA assay (Pierce).

A biotinylated phosphopeptide (sequence: Biotin-Ahx-PMQS(pT)PLN-NH${ }_{2}$ ) was diluted to $1 \mu \mathrm{M}$ (from a 2 mM DMSO stock solution) in PBS ( $\mathrm{pH} 7.4$ ) and loaded onto the wells of a 96-well Neutravidin-coated plate (Pierce) at $100 \mu \mathrm{L}$ per well for $1 \mathrm{hr}$ (background control contained only PBS). The wells were washed once with $150 \mu \mathrm{L}$ of PBST (PBS, pH 7.4 with $0.05 \%$ Tween-20), and then $100 \mu \mathrm{L}$ of $1 \%$ BSA in PBS ( $\mathrm{pH}$ 7.4) (blocking buffer) was added for $1 \mathrm{~h}$. A cytosolic lysatecontaining transiently expressed myc-tagged Plk1 protein was diluted to $150 \mu \mathrm{g} / \mathrm{mL}$ in PBS $(\mathrm{pH}$ 7.4) containing protease/phosphatase inhibitors (Pierce), mixed with competitive inhibitor (from

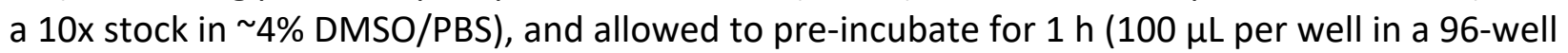
plate, $15 \mu \mathrm{g}$ total protein). The blocked ELISA plate was washed $(2 \mathrm{x})$ with PBST $(150 \mu \mathrm{L})$ and the pre-incubated lysates were added to the plate and incubated $(1 \mathrm{~h})$. The wells were washed $(4 \mathrm{x})$ with PBST $(150 \mu \mathrm{L})$ and then treated with anti-myc primary antibody (1:1500 dilution in PBS, mouse monoclonal, Pierce Biotechnology) for $1 \mathrm{~h}$. The wells were then washed (4x) with PBST $(150 \mu \mathrm{L})$ and incubated with rabbit anti-mouse IgG horseradish peroxidase (HRP) conjugate (1:3000 dilution in 1\% BSA in PBS, [Pierce]) for $1 \mathrm{hr}$. The wells were then washed $(5 \mathrm{x})$ with PBST $(150 \mu \mathrm{L})$ and incubated with Turbo $\operatorname{TMB}\left(3,3^{\prime}, 5,5^{\prime}\right.$-tetramethyl benzidine substrate)-ELISA solution (Pierce) until the desired absorbance was reached (5-10 min). The reaction was quenched by the addition of $2 \mathrm{M}$ aqueous $\mathrm{H}_{2} \mathrm{SO}_{4}$ and the absorbance was measured at $450 \mathrm{~nm}$ using a BioTek Synergy 2 plate reader. Absorbance was normalized based on the absorbance of no-inhibitor wells and plotted versus concentration $(\log \mathrm{M})$ and fit to a non-linear regression analysis using GraphPad Prism 8 software [model: $\log$ (inhibitor) vs. response-variable slope (four parameters)]. The calculated $I_{50}$ values are from multiple independent experiments and were normalized and averaged to provide values \pm SEM.

\section{Western blot analysis for cytochrome C release}

The following procedure was performed similarly to a previously described protocol. ${ }^{6} 2 \times 10^{6}$ U937 cells in $1 \mathrm{~mL}$ serum-free RPMI media was pipetted into wells of a clear, non-treated 24 well plate, followed by $10 \mu \mathrm{L}$ of $1 \mathrm{mM}$ peptide stocks (final [peptide] = $10 \mu \mathrm{M}$ ). The plate was incubated for $2 \mathrm{hr}$. Each well was transferred to $1.5 \mathrm{~mL}$ centrifuge tubes and then spun down for $5 \mathrm{~min}$ at $10,000 \mathrm{~g}$. The supernatant was discarded and the cells were resuspended in $50 \mu \mathrm{L}$ of pre-warmed lysis 1 buffer ( $20 \mathrm{mM}$ HEPES, pH 7.2 with $\mathrm{KOH}, 100 \mathrm{mM} \mathrm{KCl}, 5 \mathrm{mM} \mathrm{MgCl}, 1 \mathrm{mM}$ EDTA, $1 \mathrm{mM}$ EGTA, $250 \mathrm{mM}$ sucrose, $0.05 \%$ digitonin, supplemented with Pierce protease inhibitors). The cells were put into a heat block set at $30{ }^{\circ} \mathrm{C}$ for $45 \mathrm{~min}$, then spun down for $5 \mathrm{~min}$ 
at $10,000 \mathrm{~g}$. The supernatant (S-fraction) was removed and put on ice. The cells were resuspended in $50 \mu \mathrm{L}$ of pre-chilled lysis 2 buffer $(20 \mathrm{mM}$ Tris, $\mathrm{pH} 7.4,135 \mathrm{mM} \mathrm{NaCl}, 1.5 \mathrm{mM}$ $\mathrm{MgCl}_{2}, 1 \mathrm{mM}$ EDTA, $1 \%$ Triton X-100, $10 \%$ glycerol, supplemented with Pierce protease inhibitors). The cells were put on ice for $1 \mathrm{hr}$, then spun down for $5 \mathrm{~min}$ at 10,000 $\mathrm{g}$. The supernatant (P-fraction) was removed. $25 \mu \mathrm{L}$ of the $\mathrm{S}$ and $\mathrm{P}$ fractions for each treatment conditions were mixed with $25 \mu \mathrm{L}$ of $2 x$ laemmli sample buffer, then placed into a heat block set at $95^{\circ} \mathrm{C}$ for 5 min. $2 \times 15 \mu \mathrm{L}$ of each sample was then loaded into a 15 well Bio-Rad Mini-PROTEAN TGX gel and run for 60 min at $100 \mathrm{~V}$, with the center lane containing $4 \mu \mathrm{L}$ of the Bio-Rad Western $\mathrm{C}$ standard. The samples were then transferred to a nitrocellulose blot membrane using the BioRad Trans-Blot Turbo Transfer System. The blot membrane was stored in TBST overnight at $4{ }^{\circ} \mathrm{C}$, then cut down the center of the Western $\mathrm{C}$ standard lane. Western blotting was performed using the Invitrogen iBind Flex western system, with one half of the blot being subjected to an anticytochrome $C$ primary antibody (R\&D, clone 7H8.2C12, 1000x dilution) and the other subjected to anti-Bak (R\&D, clone 564305, 500x dilution). The secondary antibody solution for both contained anti-mouse-HRP (R\&D, cat\# HAF007, 1000x dilution) and Precision Protein StreptactinHRP (Bio-Rad, 10,000x dilution). The iBind western protocol took about $2.5 \mathrm{hr}$ to complete. The blots were then briefly placed in Milli-Q water, then transferred to western blot boxes containing $7 \mathrm{~mL}$ of SuperSignal West Pico Plus reagent. After $5 \mathrm{~min}$, the blots were imaged separately using a Bio-Rad ChemiDoc MP imager.

\section{Cell cycle analysis}

$1 \mathrm{~mL}$ of $7 \times 10^{5}$ U937 cells in complete RPMI media was pipetted into wells of a clear, non-treated 24 well plate. The plate was then incubated overnight at $37{ }^{\circ} \mathrm{C}$ with $5 \% \mathrm{CO}_{2}$ and humidity control ( $16 \mathrm{hr}$ ). The cells were then gently resuspended with a pipet, and $10 \mu \mathrm{L}$ of $1 \mathrm{mM}$ peptide stocks were added to respective wells (final [peptide] $=10 \mu \mathrm{M}$ ). For untreated cells, $10 \mu \mathrm{L}$ of Milli-Q water was added. The plate was placed back into the incubator for $24 \mathrm{hr}$. Cell cycle analysis was performed following the protocol for the BD Pharmingen - FITC BrdU Flow Kit. After treatment for $23.5 \mathrm{hr}, 10 \mu \mathrm{L}$ of $1 \mathrm{mM} \mathrm{BrdU}$ solution was added to each well with gentle resuspension/stirring and the plate was put back into the incubator for $30 \mathrm{~min}$. Each well was then transferred to a 12 $x 75 \mathrm{~mm}$ polystyrene tube and centrifuged at $300 \mathrm{~g}$ for $5 \mathrm{~min}$. The supernatant was removed and the cells were resuspended in $100 \mu \mathrm{L}$ BD Cytofix/Cytoperm solution. After 15 minutes at room temperature, $1 \mathrm{~mL}$ of BD Perm/Wash solution was added and then centrifuged at $300 \mathrm{~g}$ for $5 \mathrm{~min}$. The supernatant was removed, the cells were resuspended in $100 \mu \mathrm{L} B D$ Cytoperm permeabilization buffer solution and then put on ice for $10 \mathrm{~min} .1 \mathrm{~mL}$ of BD Perm/Wash solution was added and then centrifuged at $300 \mathrm{~g}$ for $5 \mathrm{~min}$. The supernatant was removed and the cells were resuspended in $100 \mu \mathrm{L}$ BD Cytofix/Cytoperm solution. After 5 minutes at room temperature, $1 \mathrm{~mL}$ of BD Perm/Wash solution was added and then centrifuged at $300 \mathrm{~g}$ for $5 \mathrm{~min}$. The supernatant was removed, the cells were resuspended in $100 \mu \mathrm{L}$ DNase solution $(300 \mu \mathrm{g} / \mathrm{mL}$ in PBS) and then placed back into the incubator at $37^{\circ} \mathrm{C}$ for $1 \mathrm{hr} .1 \mathrm{~mL}$ of BD Perm/Wash solution was added and then centrifuged at $300 \mathrm{~g}$ for $5 \mathrm{~min}$. The supernatant was removed, the cells were resuspended in $50 \mu \mathrm{L}$ of diluted FITC labeled anti-BrdU. After $20 \mathrm{~min}$ at room temperature, $1 \mathrm{~mL}$ of BD Perm/Wash solution was added and then centrifuged at $300 \mathrm{~g}$ for $5 \mathrm{~min}$. The supernatant was removed, the cells were resuspended in $20 \mu \mathrm{L}$ 7AAD solution and diluted with $1 \mathrm{~mL}$ of BD staining buffer. The cells were placed on ice and analyzed using a BD FACSCanto II instrument. 
Each treatment conditions were performed side-by-side with the others and were performed over three independent experiments. Datasets were analyzed using the FlowJo software to determine cell cycle populations. Statistics for different cell cycle populations and treatment conditions were computed using Graphpad Prism 8, and significance values were determined by applying two-way ANOVA analysis. 


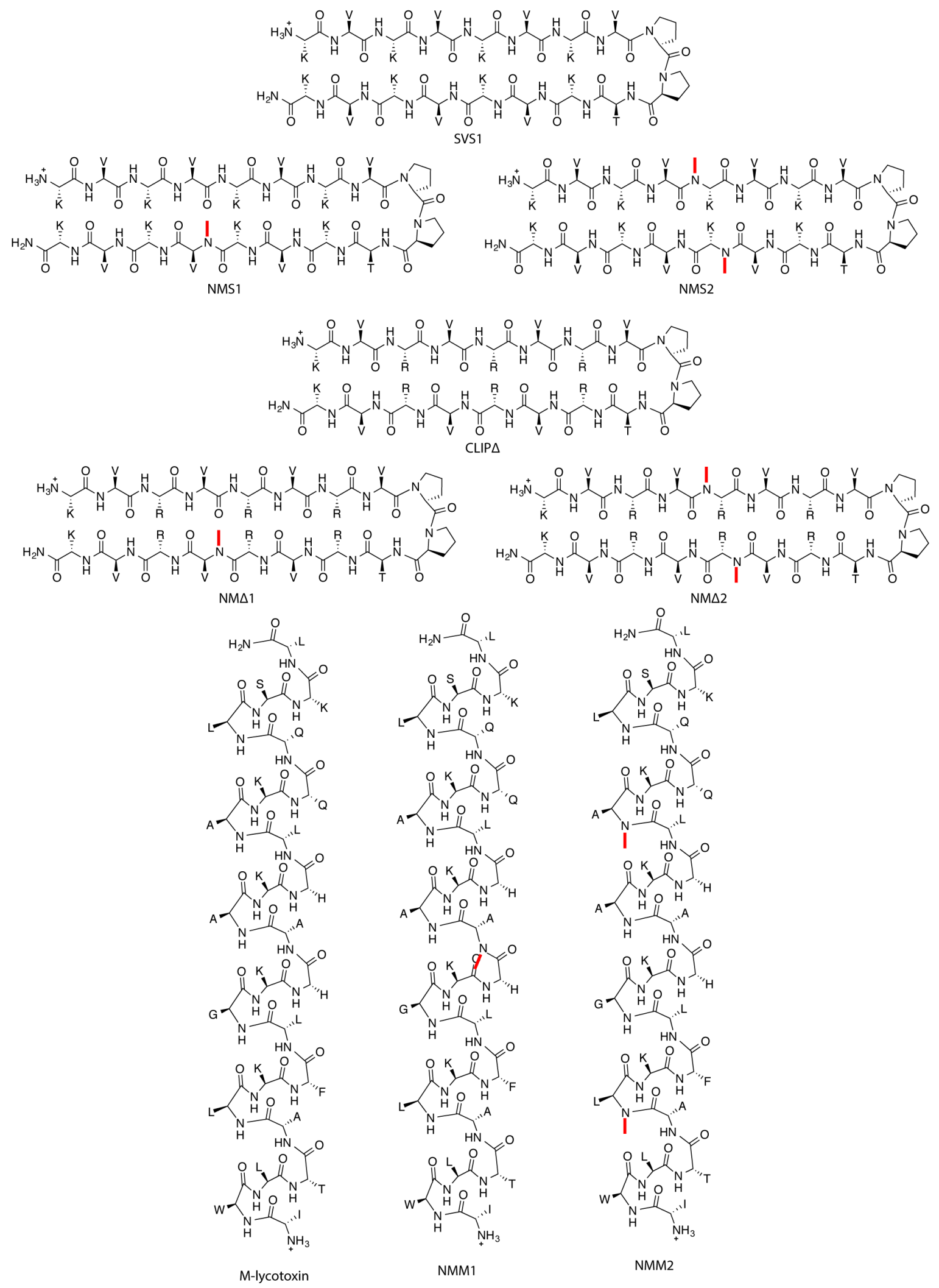

Figure S1. Structures of the lytic peptides and their respective $\mathrm{N}$-methylated analogs. A folded state is depicted for all to emphasize where hydrogen bonds are inhibited within the $\mathrm{N}$ methylated derivatives. $\mathrm{N}$-methyl groups in red. 
1.

automated

SPPS

$\overbrace{H_{2} N}^{H} N-K V K-O$

2.

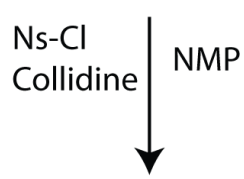

$\underset{\mathrm{NO}_{2}}{\mathrm{~N}-\mathrm{N}_{\mathrm{O}}^{\mathrm{O}}-\mathrm{N}}$
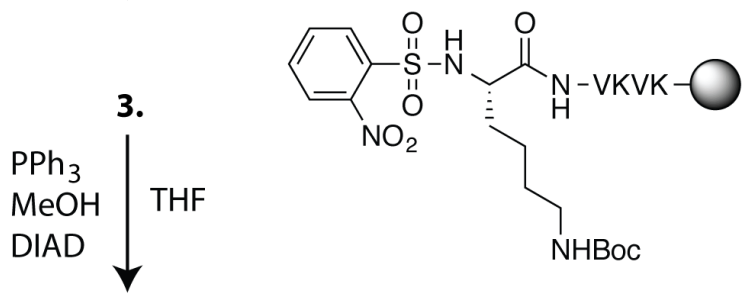

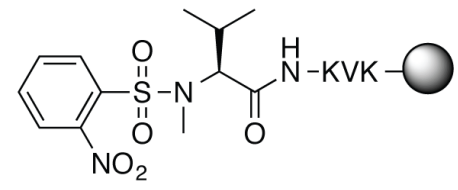
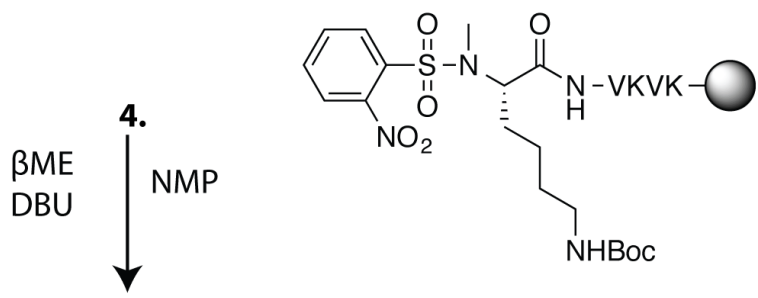

$\overbrace{O}^{H}-K V K-O$

5.
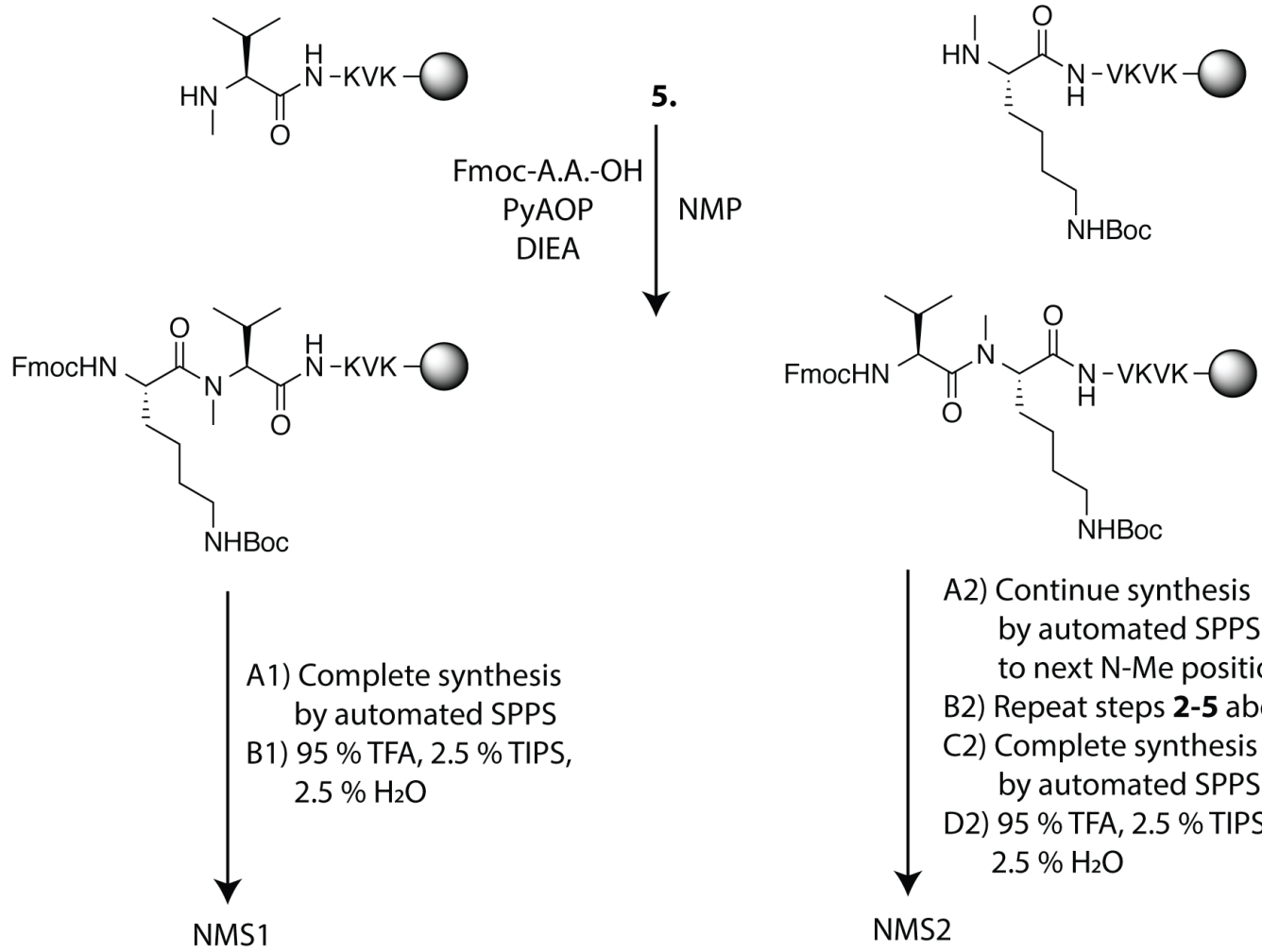

A2) Continue synthesis by automated SPPS to next N-Me position

B2) Repeat steps 2-5 above

C2) Complete synthesis by automated SPPS

D2) $95 \%$ TFA, $2.5 \%$ TIPS, $2.5 \% \mathrm{H}_{2} \mathrm{O}$

NMS2

Figure S2. General synthesis for N-methylated peptides. Shown here with NMS1 and NMS2, but respective conditions also apply to $\mathrm{NM} \Delta$ and $\mathrm{NMM}$ derivatives. 

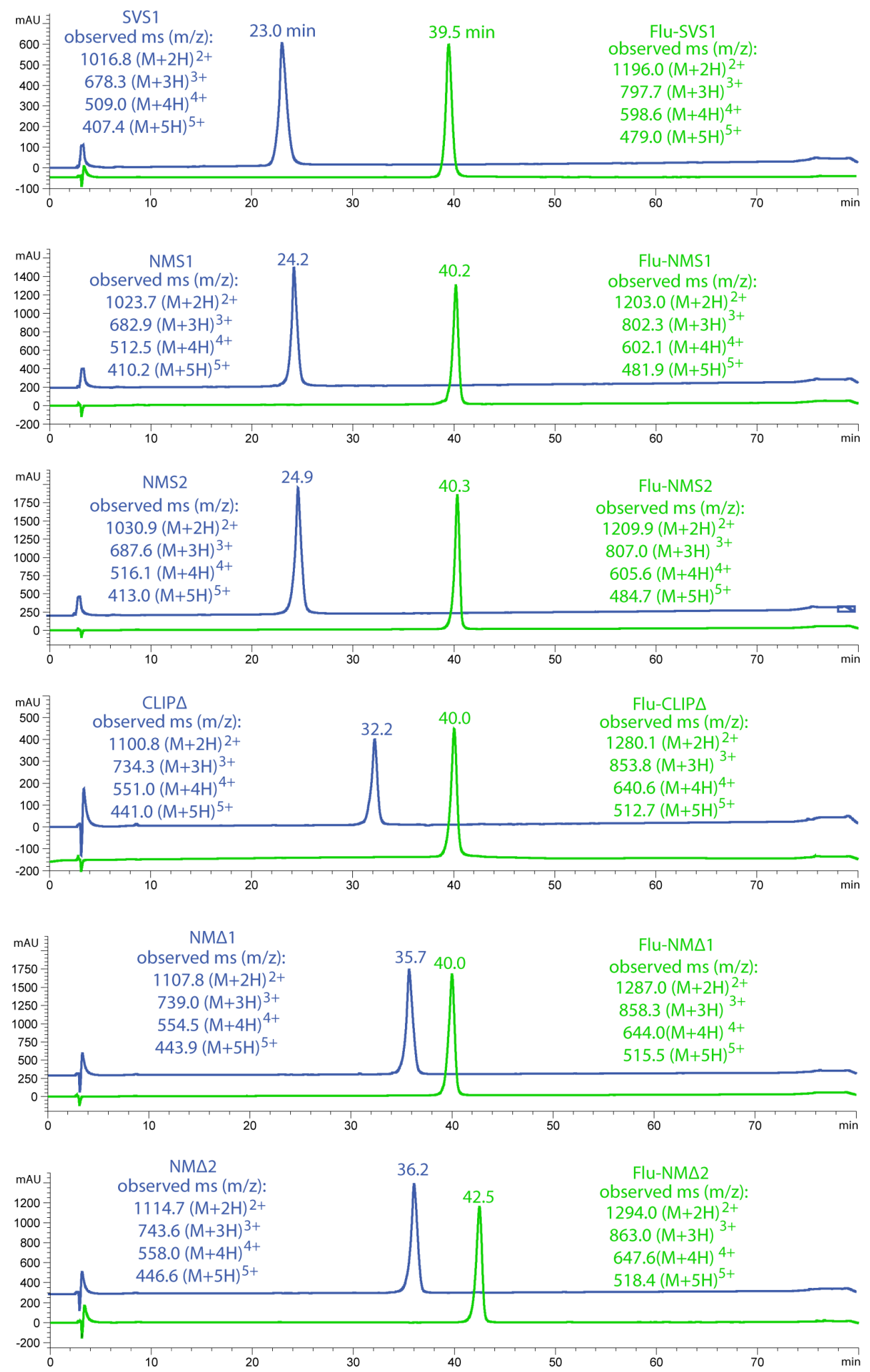

Figure S3. HPLC chromatograms and mass spectroscopy data for lytic peptides and N-methylated analogs. SVS1, NMS1, NMS2, CLIP $\Delta, N M \Delta 1, N M \Delta 2$ and respective fluorescein-labelled derivatives shown here. A mixed isomer NHS-fluorescein was used for fluorescent tagging of peptides. Figure continued on next page with M-lycotoxin derivatives. 

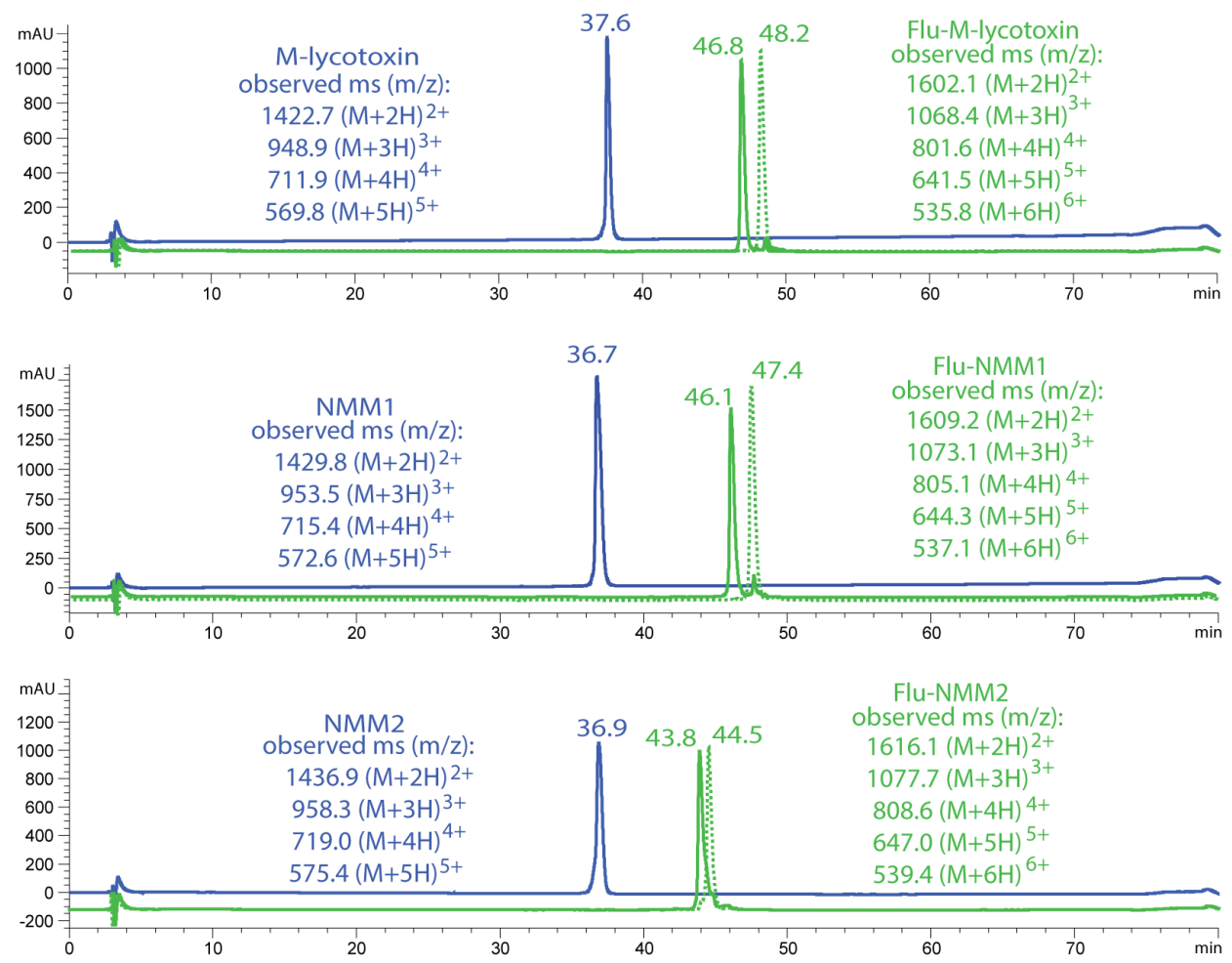

Figure S3 cont. HPLC chromatograms and mass spectroscopy data for lytic peptides and Nmethylated analogs. M-lycotoxin, NMM1, NMM2 and fluorescein-labelled respective derivatives shown here. A mixed isomer NHS-fluorescein was used for fluorescent tagging of peptides. In the case of M-lycotoxin and its derivatives, these isomers could be isolated during purification. To be consistent with the other peptides used, in which the isomers were inseparable, equal mixtures of both isomers were prepared and used in the flow cytometry studies to eliminate any potential differential uptake.
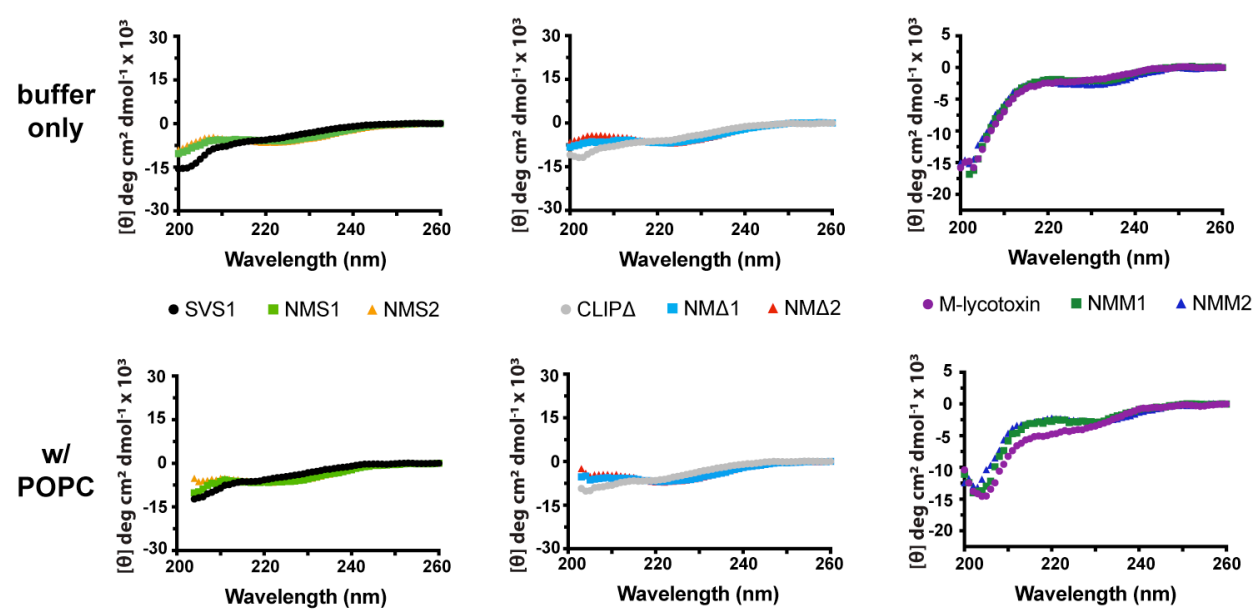

Figure S4. CD spectra for peptides in buffer alone and with neutral POPC liposomes. Peptide concentration is $50 \mu \mathrm{M}$; buffer composition is $50 \mathrm{mM} \mathrm{BTP}, 150 \mathrm{mM} \mathrm{KF}$, pH 7.4; lipid:peptide ratio is 50:1. Since liposomes cause significant light scattering at low wavelengths, data is only plotted to a lower wavelength limit as defined by acceptable dynode voltage values (<700 V). 

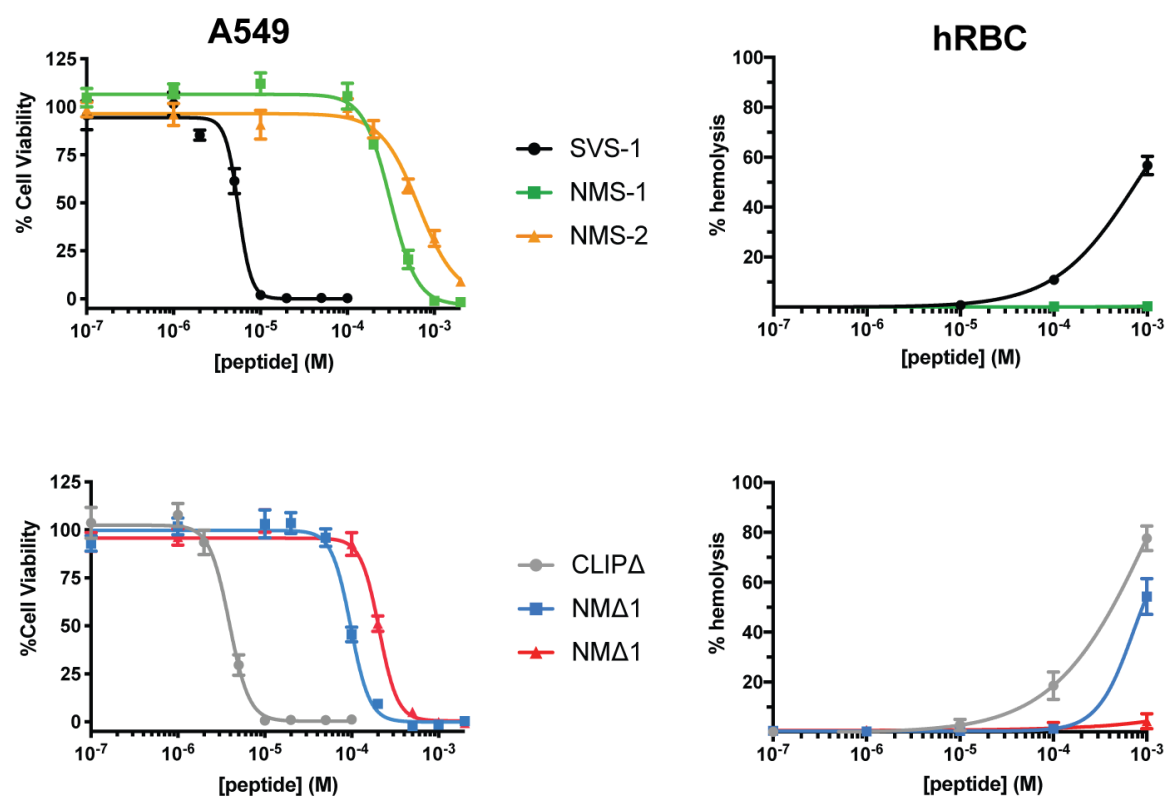

$\rightarrow$ CLIPA

$\rightarrow N M \Delta 1$

$\longleftarrow \mathrm{NM} \Delta 1$
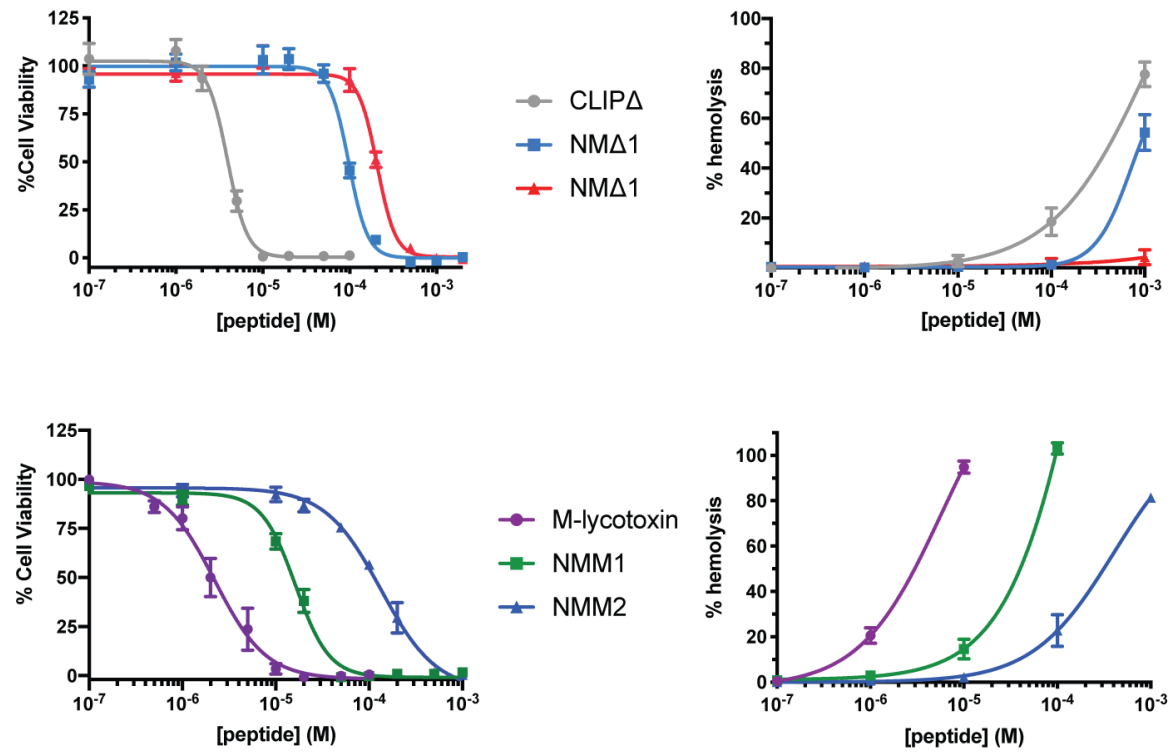

Figure S5. Cytotoxicity of peptides towards A549 and hemolytic potential. 
A)
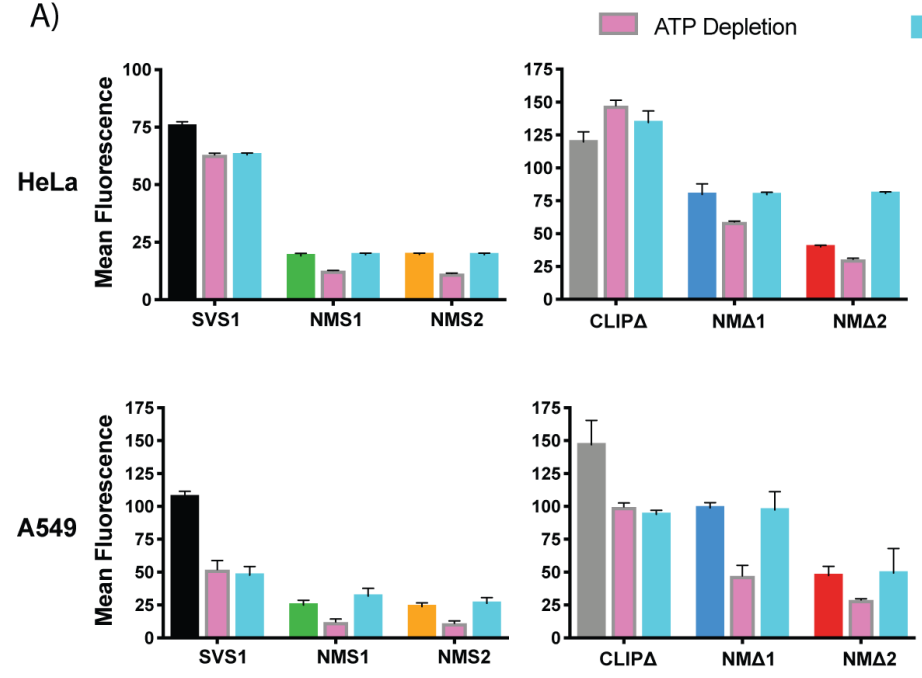

B)

$\square$ ATP Depletion $\quad 4^{\circ} \mathrm{C}$
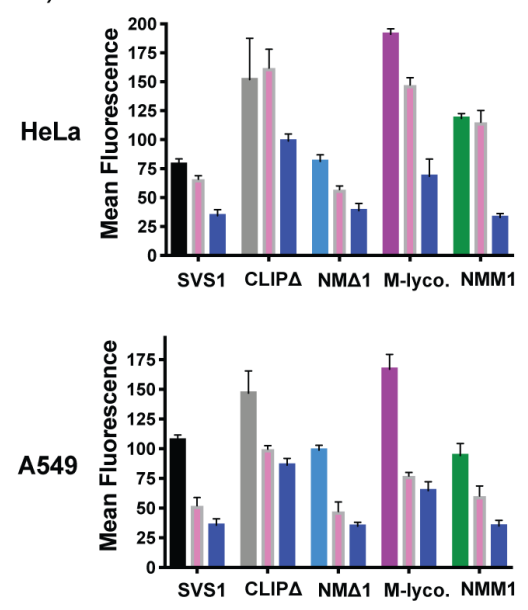

Hyperosmolar Sucrose
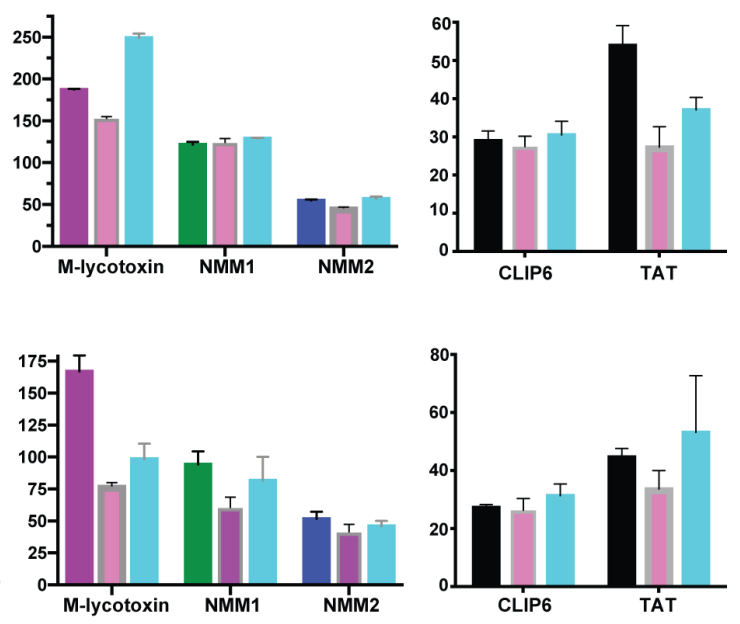

C)

II EIPA $\quad$ Nystatin
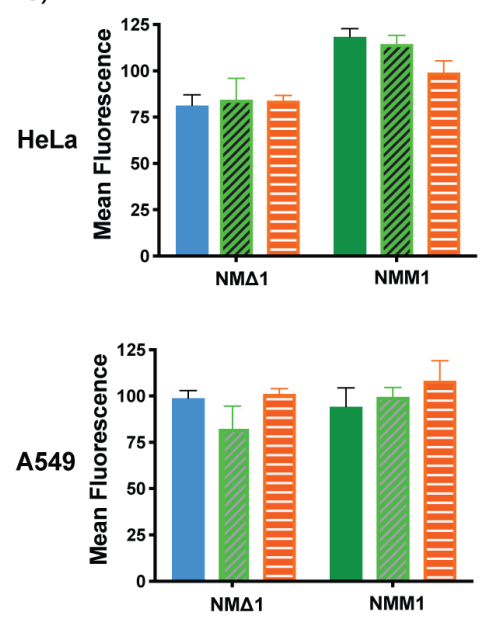

Figure S6. Uptake of fluorescein-labeled peptides. A) Flow cytometry studies for all peptides in this study $(2 \mu \mathrm{M})$. Native non-inhibiting conditions were performed in RPMI (A549) or DMEM (HeLa) (left column for each peptide). ATP depletion conditions inhibit all energy-dependent uptake (pink, middle column for each peptide), while hyperosmolar sucrose conditions inhibit clathrin-mediated endocytosis (teal, right column for each peptide). Like most CPPs, the mechanism of uptake for these peptides vary between different cell types and involve a mixture of direct translocation and energy dependent processes (CLIP6 being an exception with no active uptake when attached to fluorescein). In general, however, the N-methylated analogs seem to have little dependence on clathrin-mediated uptake, which is the most common method of endocytosis. B) Comparing the change in uptake for selected peptides when treated with ATP depletion conditions (pink, middle column for each peptide) or by performing studies at $4{ }^{\circ} \mathrm{C}$ (dark blue, right column for each peptide), both of which inhibit energy dependent uptake. Minimal differences for ATP depletion and at $4{ }^{\circ} \mathrm{C}$ experiments are observed for A549 cells, whereas peptides that can fold at cell surfaces seem to have a more drastic loss of uptake at $4{ }^{\circ} \mathrm{C}$ in HeLa cells (CLIPA, M-lycotoxin, NMM1). C) Inhibiting macropinocytosis (EIPA) and caveolaemediated endocytosis (nystatin) do not significantly alter the uptake of NM 1 or NMM1. 
A)
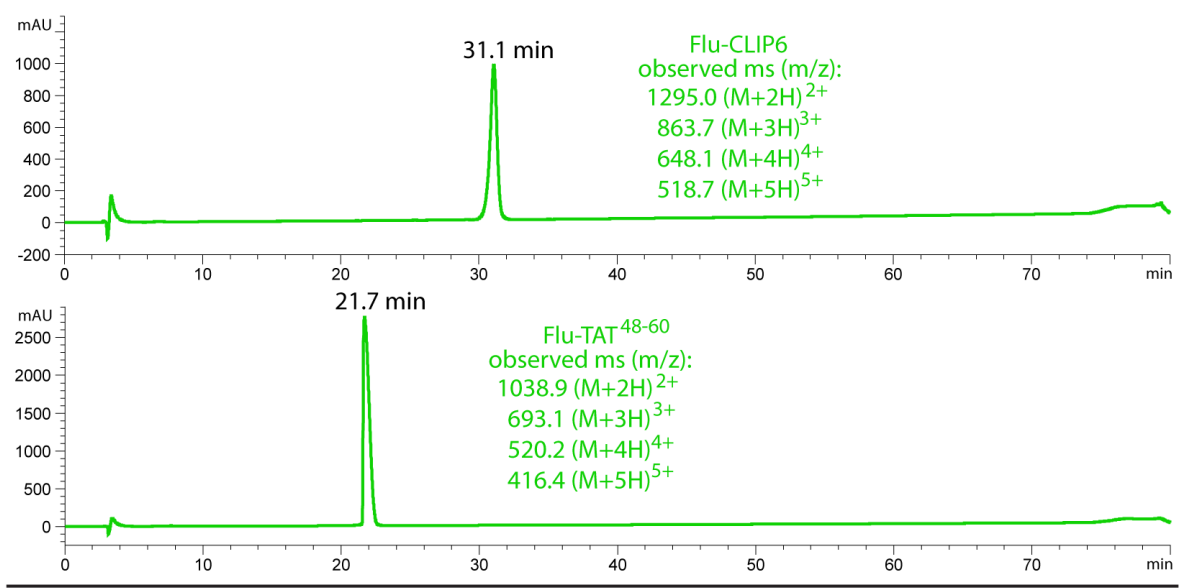

B)
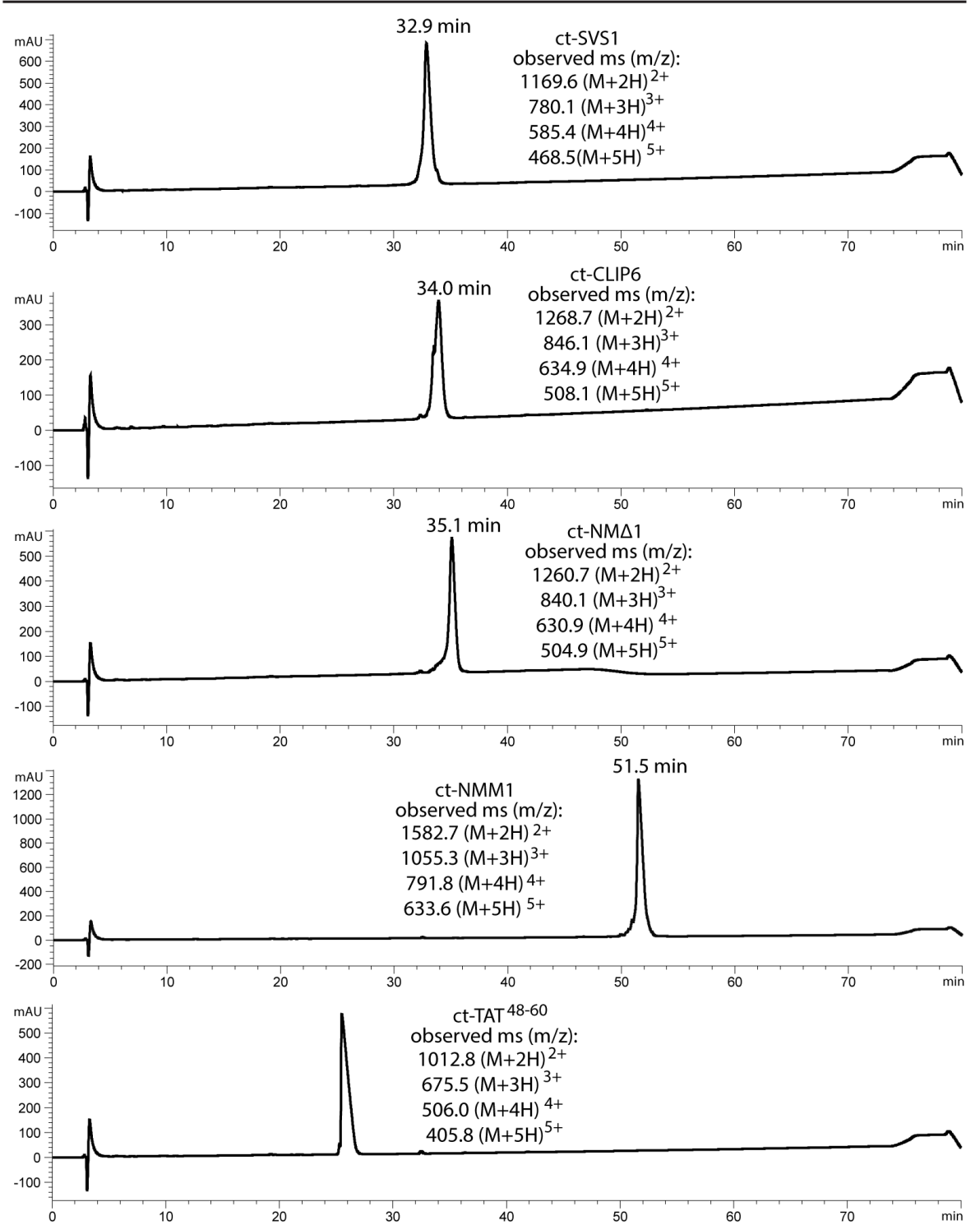

Figure S7. HPLC chromatograms and mass spectroscopy data for additional peptides. A) Fluorescently-labeled CLIP6 (Flu-KVRVRVRVDPLPTRVRERVK) and TAT (Flu-GRKKRRQRRRPPQ). B) Chloroalkane-tagged SVS1, CLIP6, NM $\triangle 1, \mathrm{NMM1}$, and TAT ${ }^{48-60}$. 
A)

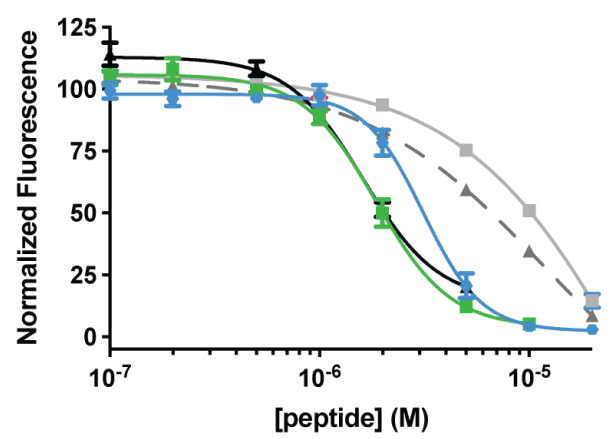

B)

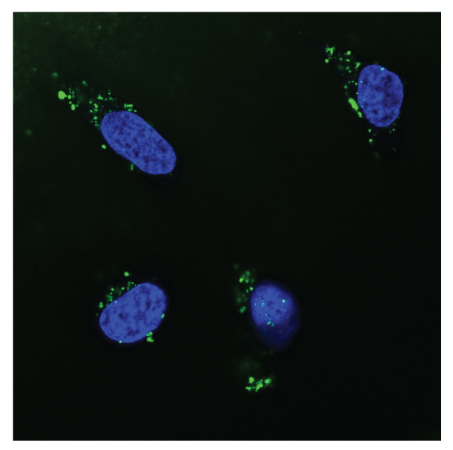

Figure S8. Additional uptake studies. A) Chloroalkane penetration assay for ct-SVS1, ct-CLIP6, ct$N M \Delta 1$, ct-NMM1, and ct-TAT ${ }^{48-60}$. HeLa cells expressing Halo-GFP-Mito in the cytoplasm were treated with ct-peptides, followed by treatment with chloroalkane-tagged Halo-TAMRA. At concentrations when the peptides do not effectively enter the cytoplasm, there will be high red fluorescence due to the Halo-TAMRA reacting with the available Halo protein. When peptides do effectively enter the cytoplasm, they will react with Halo-protein and prevent Halo-TAMRA from occupying the cytoplasm, leading to a loss of cellular red fluorescence. Determined $\mathrm{CP}_{50}$ : ct-SVS1 $=2.0 \mu \mathrm{M}$; ct-CLIP6 = $10.2 \mu \mathrm{M}$; ct-NM 1 = $3.1 \mu \mathrm{M}$; ct-NMM1 = $2.0 \mu \mathrm{M}$; ct-TAT ${ }^{48-60}=6.6 \mu \mathrm{M}$. B) Confocal microscopy of NMM1 $(5 \mu \mathrm{M})$ in HeLa cells (not transfected with Halo-GFP-Mito).
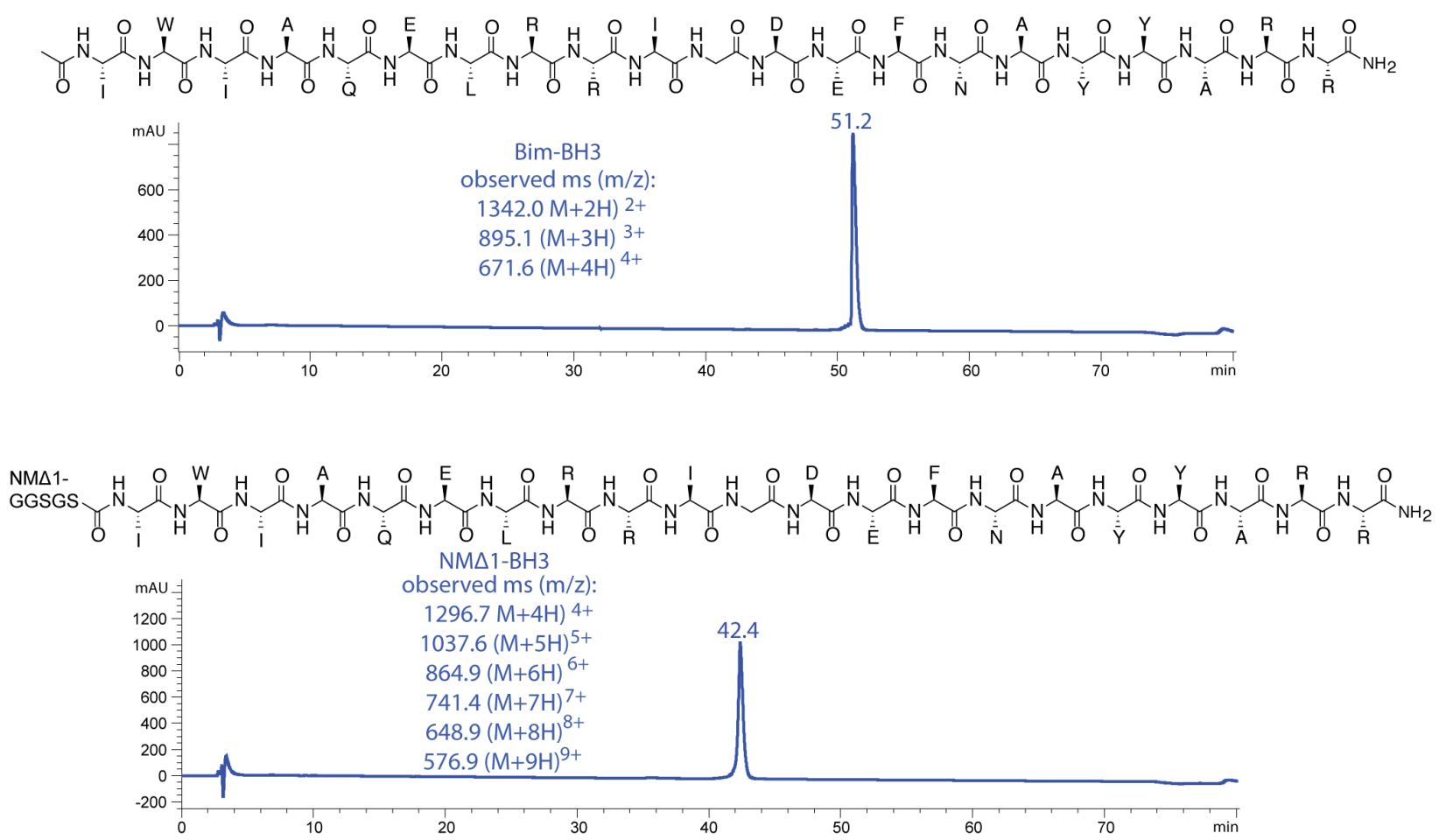

Figure S9. HPLC chromatograms and mass spectroscopy data for $\mathrm{BH} 3$ peptides. The synthesis of the NM $\triangle 1-B H 3$ conjugate required further optimization, which can be found in the synthesis portion of the methods section above. 


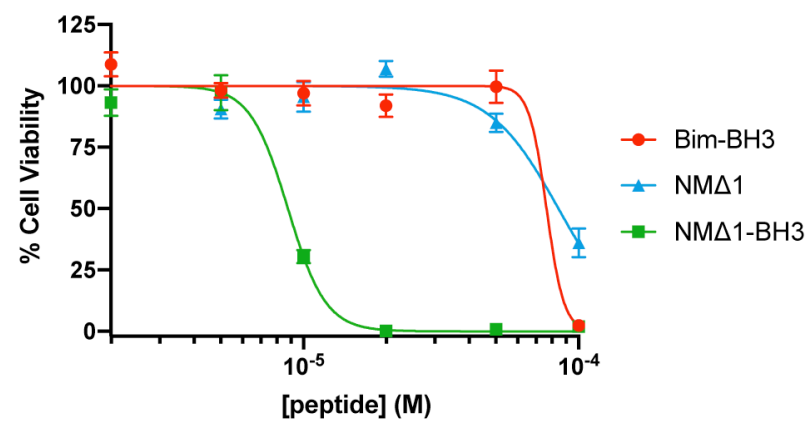

Figure S10. Cytotoxicity of BH3 peptides towards A549 cells. 
A)
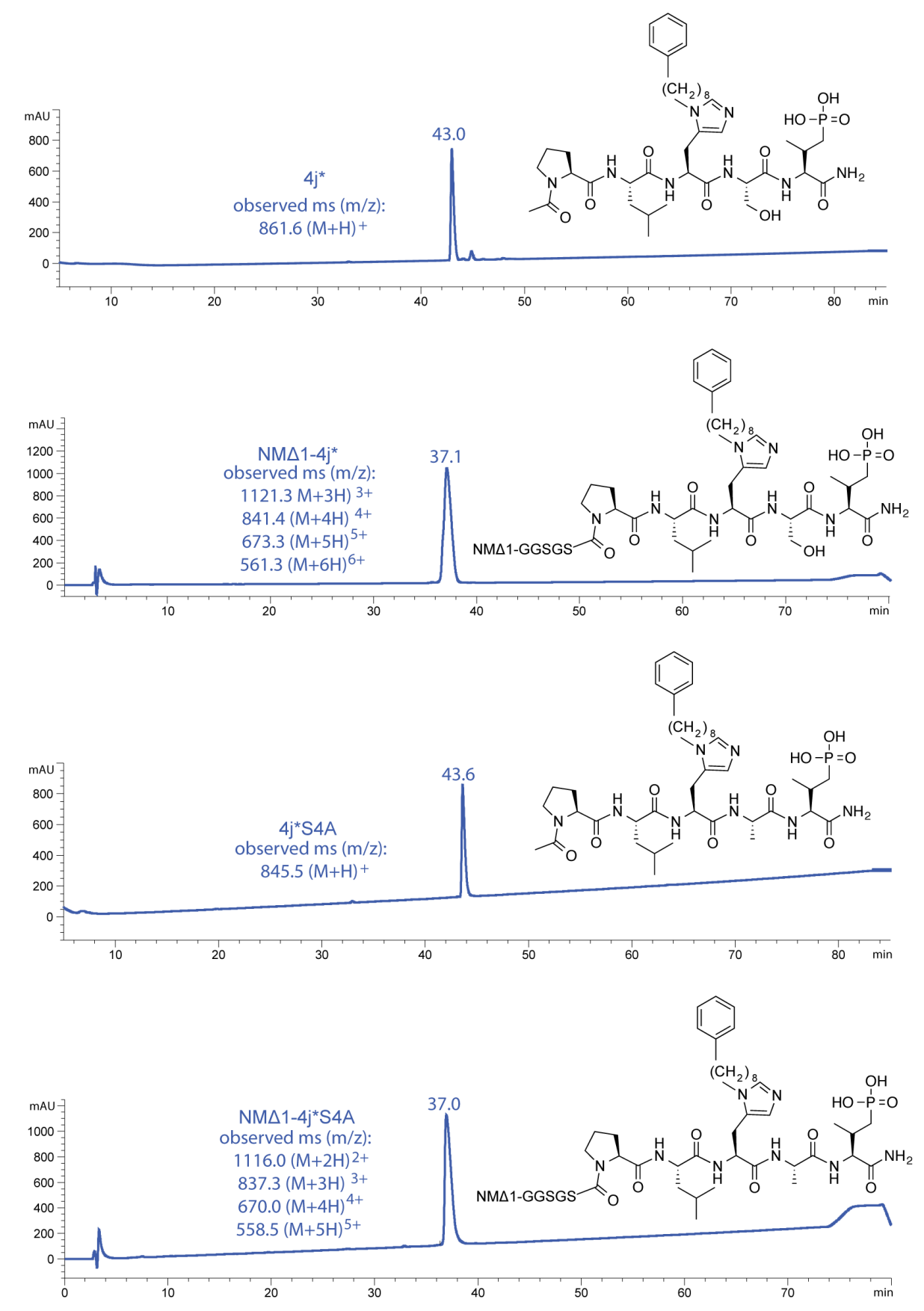

B)

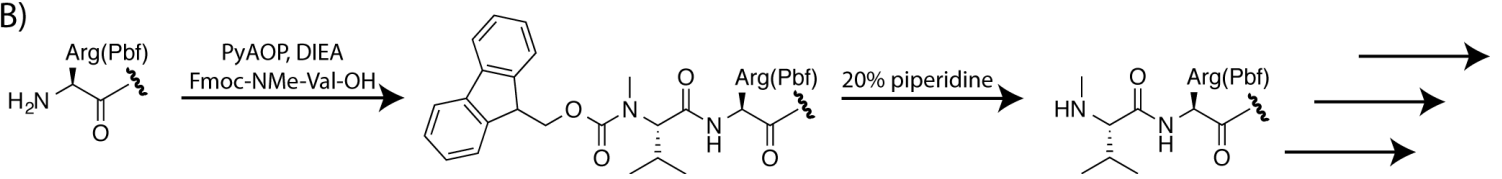

Figure S11. Analysis and N-methylation of $4 \mathrm{j}^{*}$ peptides. A) HPLC chromatograms and mass spectroscopic data. B) For synthesis of $N M \Delta 1$ conjugates, direct coupling of $\mathrm{N}$-methylated amino acid was performed rather than Fukuyama-Mitsunobu conditions due to methylation of the modified His residue on $4 j^{*}$. Remaining synthesis was done as before. 


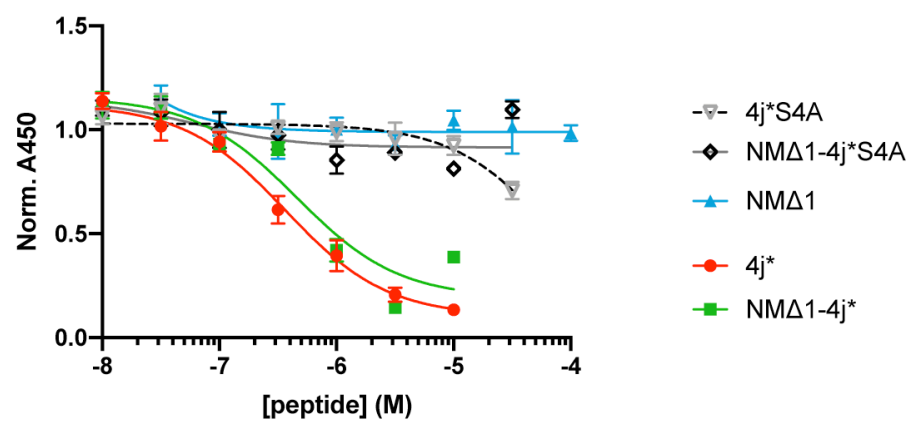

Figure S12. In vitro binding to PIk1. HEK293T cells were transfected to overexpress myc-Plk1 and lysates were mixed with varying concentrations of peptides. The mixtures were added to 96 well plates coated with a Plk1-binding peptide and subjected to ELISA, with an anti-myc primary antibody and an HRP-conjugated secondary antibody.
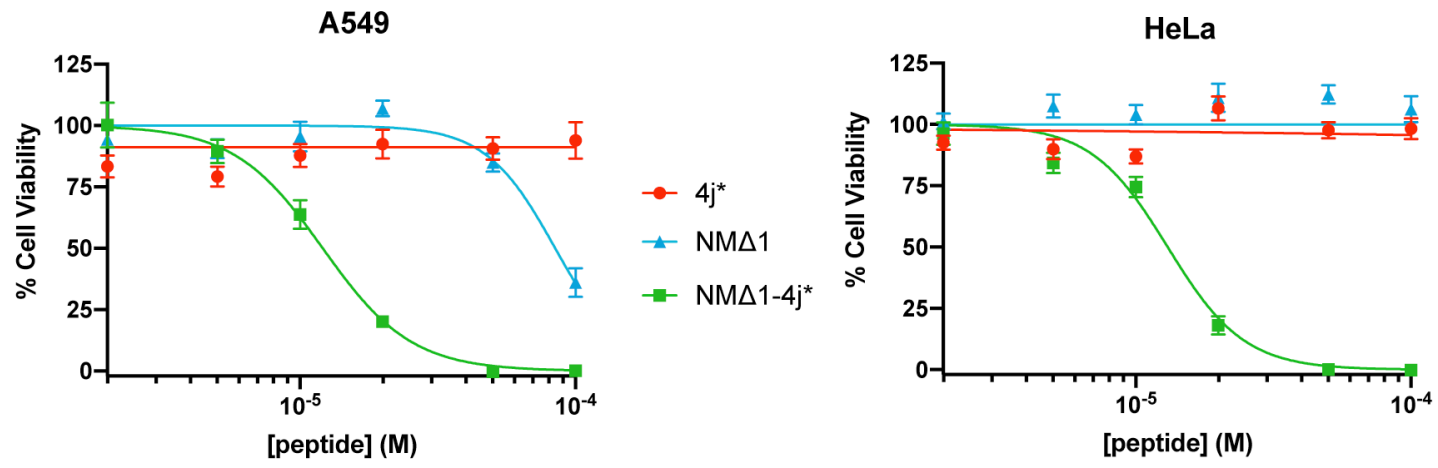

Figure S13. Cytotoxicity of $4 j^{*}$ peptides towards A549 and HeLa cells. 

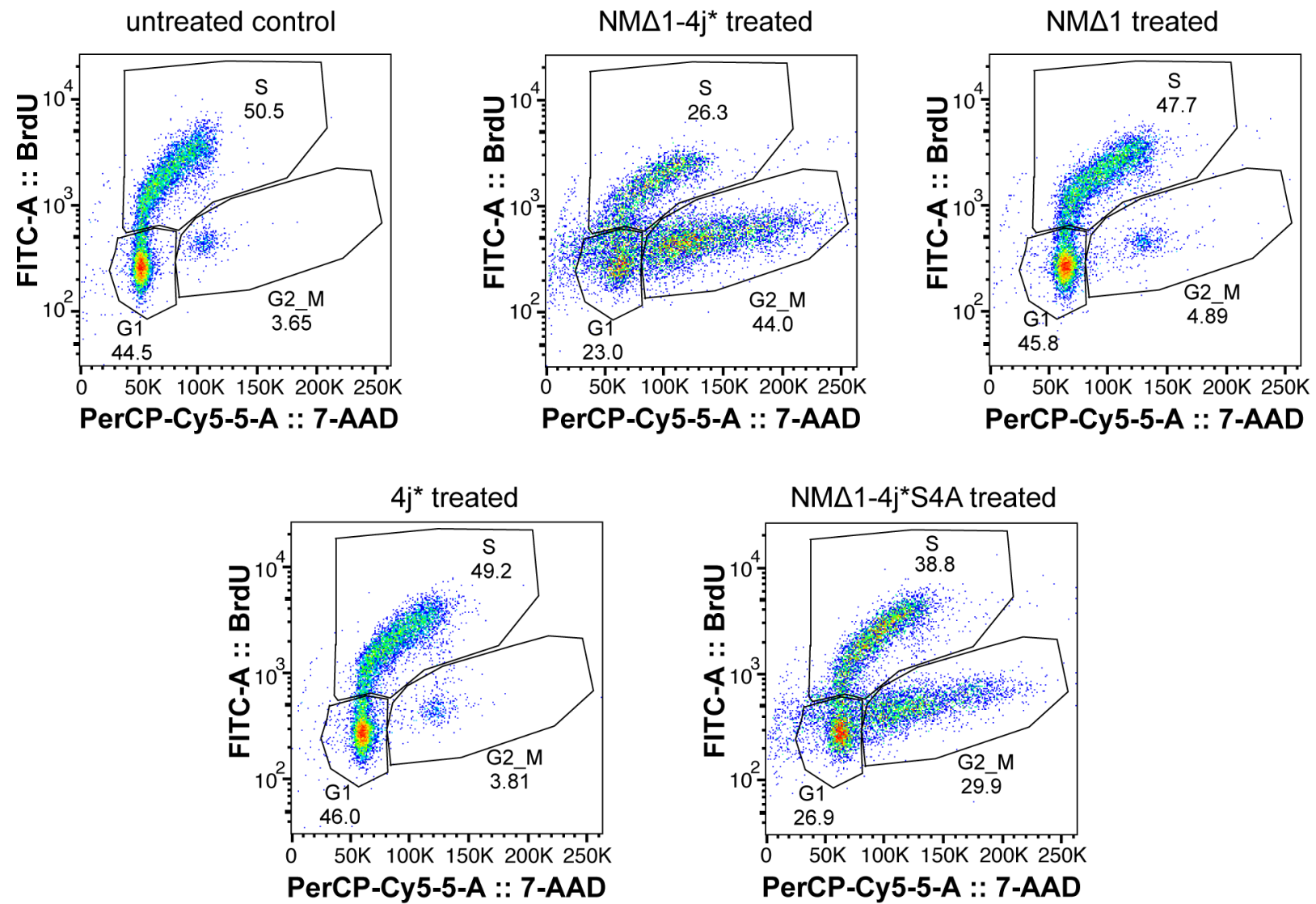

Figure S14. Representative cell cycle dot plots for side-by-side treatment of U937 cells. Cells were treated with $10 \mu \mathrm{M}$ peptide for $24 \mathrm{hr}$ and subjected to the BD FITC-BrdU flow kit. After data collection for each experiment, consistent gating was applied to all treatment conditions.

$\mathrm{NM} \Delta 1 \mathrm{NM} \Delta 1$

$-\mathrm{BH} 3 \quad-4 \mathrm{j}^{*}$

$(0.5 \mathrm{hr})(2 \mathrm{hr})$

\section{\begin{tabular}{ll|ll|}
\hline $\mathrm{P}$ & $\mathrm{S}$ & $\mathrm{P}$ & $\mathrm{S}$
\end{tabular} \\ anti-Cyt C \\ anti-Bak}

Figure S15. U937 western blot analysis for cytochrome $\mathrm{C}$ release, NM $\Delta 1-4 \mathrm{j}^{*}$ vs NM $\Delta 1-\mathrm{BH}$. Both treatments were of $10 \mu \mathrm{M}$ peptide. $\mathrm{NM} \Delta 1-\mathrm{BH} 3$ had rapid cytochrome $\mathrm{C}$ release in under an hour, while there was none for $N M \Delta 1-4 j^{*}$ after $2 \mathrm{hr}$. This is consistent with the proposed mechanism of cell death for $N M \Delta 1-4 j^{*}$, where cell cycle needs to be disrupted prior to the initiation of apoptosis. 


\section{Supporting References}

1. Peraro, L.; Deprey, K. L.; Moser, M. K.; Zou, Z.; Ball, H. L.; Levine, B.; Kritzer, J. A., Cell Penetration Profiling Using the Chloroalkane Penetration Assay. J. Am. Chem. Soc. 2018, 140 (36), 11360-11369.

2. Sinthuvanich, C.; Veiga, A. S.; Gupta, K.; Gaspar, D.; Blumenthal, R.; Schneider, J. P., Anticancer beta-Hairpin Peptides: Membrane-Induced Folding Triggers Activity. J. Am. Chem. Soc. 2012, 134 (14), 6210-6217.

3. Deprey, K.; Kritzer, J. A., Chapter Twelve - Quantitative measurement of cytosolic penetration using the chloroalkane penetration assay. In Method Enzymol, Chenoweth, D. M., Ed. Academic Press: 2020; Vol. 641, pp 277-309.

4. Ballister, E. R.; Aonbangkhen, C.; Mayo, A. M.; Lampson, M. A.; Chenoweth, D. M., Localized light-induced protein dimerization in living cells using a photocaged dimerizer. Nat. Commun. 2014, 5 (1), 5475.

5. Hymel, D.; Burke Jr., T. R., Phosphatase-Stable Phosphoamino Acid Mimetics That Enhance Binding Affinities with the Polo-Box Domain of Polo-like Kinase 1. ChemMedChem 2017, 12 (3), 202-206.

6. Checco, J. W.; Lee, E. F.; Evangelista, M.; Sleebs, N. J.; Rogers, K.; Pettikiriarachchi, A.; Kershaw, N. J.; Eddinger, G. A.; Belair, D. G.; Wilson, J. L.; Eller, C. H.; Raines, R. T.; Murphy, W. L.; Smith, B. J.; Gellman, S. H.; Fairlie, W. D., $\alpha / \beta$-Peptide Foldamers Targeting Intracellular Protein-Protein Interactions with Activity in Living Cells. J. Am. Chem. Soc. 2015, 137 (35), 11365-11375. 